\title{
DOS MODELS D'ECONOMIES PERIFÈRIQUES ANTAGÒNICS DES DE LA PERSPECTIVA DE LA JUSTÍCIA AMBIENTAL: LA RIBERA D'EBRE I EL PRIORAT
}

\section{TWO MODELS OF ANTAGONIC PERIPHERAL ECONOMIES FROM THE PERSPECTIVE OF ENVIRONMENTAL JUSTICE: THE SHORE OF THE EBRO AND THE PRIORAT}

\author{
XaVIeR MiLIAN NeBOT \\ Universitat de València \\ xavimiliannebot@gmail.com
}

Data de recepció: 1 de abril de 2019 / Data d'acceptació: 30 de setembre de 2019

RESUM: La Ribera d'Ebre i el Priorat són dos exemples paradigmàtics d'economies perifèriques tenint en compte la seva estructura productiva. Tanmateix, en les darreres dècades ambdues comarques plantegen un model de desenvolupament socioeconòmic divergent que es tradueix en un model de justícia ambiental antagònic: mentre a la Ribera d'Ebre s'intensifica el caràcter d'economia dependent en base a un model de producció extractiu al Priorat s'assaja un model de desenvolupament endogen com a model alternatiu d'explotació dels recursos naturals, impulsat per la societat civil i les institucions públiques. Aquesta disjuntiva planteja la necessitat d'afrontar un debat sobre la legislació vigent, que no sols planteja reptes importants respecte la justícia ambiental que cal introduir en la nova producció legislativa, sinó que també té un fort impacte en el model de desenvolupament socioeconòmic d'aquestes comarques, que pot representar un punt d'inflexió amb el model imposat durant la segona meitat del segle XX.

RESUMEN: La Ribera d'Ebre y el Priorat son dos ejemplos paradigmáticos de economías periféricas según su estructura productiva. Sin embargo, en las últimas décadas ambas comarcas plantean un modelo de desarrollo socioeconómico divergente que se traduce en un modelo de justicia ambiental 
antagónico: mientras en la Ribera d'Ebre se intensifica el carácter de economía dependiente en base a un modelo de producción extractivo en el Priorat se ensaya un modelo de desarrollo endógeno como modelo alternativo de explotación de sus recursos naturales, impulsado por la sociedad civil y las instituciones públicas. Esta disyuntiva plantea la necesidad de afrontar un debate sobre la legislación vigente, que no solo plantea retos importantes respeto la justicia ambiental que hay que introducir en la nueva producción legislativa, sino que también tiene un fuerte impacto en el modelo de desarrollo socioeconómico de estas comarcas, que puede representar un punto de inflexión con el modelo impuesto durante la segunda mitad del siglo XX.

ABSTRACT: Ribera d'Ebre and Priorat are two paradigmatic examples of peripheral economies taking into account its productive structure. However, in the last decades, both regions present a divergent socio-economic development that becomes an antagonic socio-economic development model: whereas the development character of economy is intensified according to a model of extractive production in Ribera d'Ebre, in Priorat, an endogenous model of development is tested as an alternative model of development of exploitation of natural resources which is motivated by civil society and public institutions. This quandary sets outs the need to face up a debate about the current law that not only its sets out important challenges related to environmental justice that has to be introduced in the new production of laws, but also it has a strong impact on the socio-economic development of these regions that can represent an inflection point of the imposed model during the second half of the Twentieth Century.

PARAULES CLAU: Justícia ambiental - Economia perifèrica - Economia dependent - Desenvolupament endogen - Model de desenvolupament socioeconòmic

PALABRAS CLAVE: Justicia ambiental - Economía periférica - Economía dependiente - Desarrollo endógeno - Modelo de desarrollo socioeconómico KEYWORDS: Environmental justice - Peripheral economy - Dependent economy - Endogenous development - Model of socio-economic development 
SUMARI: I. Teoria de la dependència i justícia ambiental. II. El caràcter perifèric de les comarques de la Ribera d'Ebre i el Priorat. III. La construcció de dos models de desenvolupament antagònics IV. Conclusions. V. Bibliografia.

\section{TEORIA DE LA DEPENDĖNCIA I JUSTÍCIA AMBIENTAL}

A partir de la dècada dels 60 i 70 sorgeix una corrent acadèmica, bàsicament formada per historiadors i economistes, que pretén posar les bases científiques per explicar la situació d'estancament econòmic d'Amèrica Llatina durant el segle XX, el que s'ha denominat com a economies o països "subdesenvolupats".

La teoria del sistema-món ${ }^{1}$ plantejarà la base teòrica, a partir de la qual, es desenvoluparà I'anàlisi d'aquesta corrent. En síntesi, aquest esquema d'interpretació de la història moderna planteja que s'ha conformat un procés històric des del segle XV -amb l'aparició del mercantilisme i una nova classe social emergent- que ha creat un sistema econòmic dominant a nivell mundial, el qual atorga a les diferents zones geogràfiques que el conformen un rol determinat dins d'aquest sistema que determina el seu model desenvolupament econòmic: centre, semiperifèria i perifèria.

Partint d'aquesta premissa teòrica, un grup d'acadèmics d'aquesta corrent desenvoluparà la teoria de la dependència, en que desenvolupen el rol perifèric d'aquest sistema-món, arribant a la conclusió que existeixen unes relacions desiguals entre centre-perifèria, en la que els segons estan subordinats econòmic, social i políticament als interessos dels primers, el que determina les relacions entre ells, i a la vegada, amplia progressivament la dependència entre els països de la perifèria i els del centre ${ }^{2}$.

Com a conseqüència d'aquest model de dependència a les economies centrals del sistema-món, els països perifèrics es caracteritzen per un model de

\footnotetext{
1 Els principals autors que elaboren aquesta teoria són, Immanuel Wallerstein, El moderno sistema mundial, Siglo XXI Editores. Madrid, 2010 (2a edició en 4 volums); Fernand Braudel, Civilización material, economía y capitalismo, Alianza Editorial. Madrid, 1984 (1a edició en 3 volums); Giovanni Arrighi, Caos y orden en el sistema-mundo moderno, Akal. Madrid, 2001 (1a edició).

2 Les principals obres que desenvolupen aquesta teoria són, André Gunder Frank, Capitalismo y subdesarrollo en América Latina, Siglo XXI Editores. México DF, 1976 (1a edició); Samir Amin, El desarrollo desigual. Ensayo sobre las formaciones sociales del capitalismo periférico, Editorial Fontanella. Barcelona, 1975 (2a edició); Theontonio Dos Santos, Imperialismo y dependencia, Ediciones Era. México DF, 1978 (1a edició).
} 
subdesenvolupament, que no els permet desenvolupar determinats serveis 0 capacitats productives, a causa d'aquesta subordinació. Per aquest motiu, aquests països mai podran desenvolupar un model productiu similar als dels estats centrals del sistema-món, ja que posarien en perill l'equilibri del sistemamón en sí mateix. I, segons aquesta mateixa lògica, aquesta estructura explicaria la causa del fracàs de les "polítiques de desenvolupament" que s'han intentat implementar en els països perifèrics per ordre del Banc Mundial i el Fons Monetari Internacional per tal d'intentar desenvolupar les seves estructures productives a imitació dels estats centrals ${ }^{3}$.

Entre les característiques comunes de les economies perifèriques hi trobem que aquestes es dediquen bàsicament a la producció de les matèries primeres (model d'economia extractiva) que necessiten les economies centrals per a desenvolupar els processos industrials de major valor afegit (model d'economia d'enclavament ${ }^{4}$ ), així com que les relacions comercials que uneixen aquestes dues economies beneficien als interessos dels estats centrals, ja que aquests són els qui tenen el poder polític i econòmic per a poder establir les condicions que li són més beneficiàries.

Però, aquest model de dependència no es produeix només entre els diferents països que ocupen un rol perifèric en el marc del sistema-món, sinó que també es reprodueix en les diferents regions que conformen un mateix Estat-nació ${ }^{5}$. Una de les conseqüències d'aquest model de desenvolupament econòmic i territorial atempta directament contra el medi ambient. La subordinació de les economies perifèriques a les economies centrals, provoca que tots aquells processos productius que impliquin majors efectes externs negatius sobre els recursos i la població d'un territori, recaiguin precisament en les primeres.

Arran d'aquest fenomen, a finals del segle passat i a començaments del present, es desenvolupa la teoria de la justícia ambiental. L'origen d'aquesta corrent $^{6}$ cal ubicar-la a la dècada dels 80 , quan s'observa que en determinades

\footnotetext{
${ }^{3}$ Sobre aquesta qüestió, podeu consultar Noam Chomsky, El Nuevo Ordre Mundial (y el viejo), Editorial Crítica. Madrid, 1996 (1a edició); Samir Amin, Decadencia y crisis del capitalismo actual, Editorial Zero. Madrid, 1978 (1a edició).

${ }^{4}$ Concepte desenvolupat per Paul A Baran, La economía política del crecimiento, Fondo de Cultura Económica. México DF, 1959 (4a edició).

5 Aquesta teoria és desenvolupada per Magnus Blomström i Björn Hettne, La teoría del desarrollo económico en transición, Fondo de Cultura Económica. México DF, 1990 (1a edició).

${ }^{6}$ Sobre els orígens d'aquesta corrent, podeu consultar Iván López, "Justicia ambiental", en Eunomía. Revista en Cultura de la Legalidad, núm. 6, 2014, o Adriana Espinosa González, "La
} 
zones d'Estats Units habitades per minories ètniques o persones amb menors recursos econòmics, tendien a acumular totes aquelles activitats contaminants -principalment abocadors de residus- que no generaven riquesa, sinó que encara tendien més a cronificar la desigualtat social amb les zones més benestants de les ciutats o del país ${ }^{7}$.

De la confluència d'aquestes lluites socials en contra d'aquests projectes contaminants, l'any 1991 s'organitza el The People of Color Environmental Leadership Summit a la capital dels Estats Units, en el qual s'aprova un manifest de reivindicacions basant-se en el principi de justícia ambiental ${ }^{8}$, que tindrà com a conseqüència que l'any 1994 el govern dels Estats Units tingui en compte aquestes reclamacions a l'hora de dissenyar les polítiques d'instal·lació d'aquestes indústries contaminants.

Després d'aquesta fita, al llarg de la primera dècada del segle XXI prendrà forma el concepte de justícia ambiental ${ }^{9}$, tenint en compte la relació entre ètnia, classe social i riscos medioambientals, que permetran actuar des d'una perspectiva econòmica (polítiques de desenvolupament), medioambiental (desenvolupament sostenible) i social (polítiques redistributives).

Des de diferents àmbits universitaris (dret ambiental, ecologia política, geografia...) el concepte de justícia ambiental s'ha anat desenvolupant, tot i que encara no ha estat capaç d'introduir-se en les institucions que tenen la potestat de legislar i desenvolupar la planificació territorial.

Tanmateix, la importància creixent de les polítiques públiques per a la protecció del medi ambient, haurien de permetre "avançar cap a una distribució equitativa de les càrregues i beneficis del metabolisme social, cosa que ve propugnada per la idea de justícia ambiental. En aquest sentit, la consciència del potencial de transformació humana, que obligaria a reconsiderar l'estructura institucional

justicia ambiental, hacia la igualdad en el disfrute del derecho a un medio ambiente sano", en Universitas. Revista de Filosofía, Derecho y Política, núm. 16, 2012.

${ }^{7}$ L'estudi més conegut sobre aquesta qüestió és Christopher H Foreman, The promise and peril of environmental justice, Brookings Institution Press. Washington, 1998 (1a edició).

8 Podeu consultar el text a <http://www.ejnet.org/ej/principles.html> [Darrera consulta 25 de març de 2019].

${ }^{9}$ Entre les principals obres i autores que desenvolupen aquest concepte podem trobar Robert D Bullard, "Dismantling Environmental Racism in the USA", en Local Environment, vol. 4, núm. 1, 1999, Feng Liu, Environmental Justice Análisis. Theories, methods and practice, Lewish Publishers. Londres, 2001 (1a edició); PS Wenz, Environmental Justice, State University of New York Press. Albany, 1988 (1a edició) o Joan Martínez Alier, El ecologismo de los pobres. Conflictos ambientales y lenguajes de valoración, Icaria Editorial. Barcelona, 2004 (1a edició). 
i les tècniques de disciplina social per governar adequadament l'acció antròpica en relació amb el seu impacte en la configuració del Sistema Terra, s'hauria de canalitzar a través d'estratègies d'acció social conscients del caràcter inequitatiu dels processos de transformació antròpica fins al present, tot introduint la noció de justícia ambiental, tant en l'eix sincrònic, com en l'eix diacrònic"10.

\section{EL CARÀCTER PERIFÈRIC DE LES COMARQUES DE LA RIBERA D'EBRE I EL PRIORAT}

A mitjans del segle XIX es produeix la Revolució Industrial a Catalunya, mitjançant el desenvolupament de la indústria tèxtil a les ciutats costaneres i a les ribes dels principals rius de la meitat septentrional del país. Es tracta d'un model d'indústria lleugera que s'allunya de la indústria pesada dels estats centrals del sistema-món, a causa de la manca de recursos naturals (bàsicament carbó) que permetin obtenir la energia suficient per a aquest tipus d'indústria.

Tanmateix, la manca d'industrialització a la resta de l'Estat espanyol, que a excepció del País Basc no arribarà fins a mitjans del segle $X X$, fa que Catalunya esdevingui la principal potència industrial de l'Estat, ubicant-se aquest en la semiperifèria del sistema-món a causa del predomini d'una activitat primària rudimentària i basada en el latifundisme ${ }^{11}$.

Dins del territori català, les comarques del Priorat i la Ribera d'Ebre quedaran al marge d'aquest procés de Revolució Industrial. Com moltes altres comarques d'interior i de muntanya, la contribució d'aquestes comarques al procés d'industrialització català, consistirà en aportar mà d'obra no qualificada per cobrir llocs de peonatge a les manufactures i a les fàbriques del pla de

\footnotetext{
10 Jordi Jaria i Manzano, "El dret, l'antropocè i la justicia", en Revista Catalana de Dret Ambiental, vol. VIII, núm. 2, 2016.

11 Sobre el fracàs de la Revolució Industrial a l'Estat espanyol i les seves conseqüències econòmiques, polítiques i socials, podeu consultar Jordi Nadal i Oller, El fracaso de la revolución industrial en España (1814-1913), Editorial Crítica. Barcelona, 2009 (1a edició), Josep Fontana, Cambio económico y actitudes políticas en la España del siglo XIX, Editorial Ariel. Barcelona, 1975 (1a edició) o Miquel Izard, Manufactureros, industriales $y$ revolucionarios, Editorial Crítica. Barcelona, 1979 (1a edició).
} 
Barcelona, o en el cas de les comarques que ens ocupen, també de Reus i Tortosa.

La única excepció d'aquest monopoli de l'activitat primària en aquestes comarques es produirà l'any 1897, quan una empresa alemanya s'instal-larà a la riba de l'Ebre ${ }^{12}$, a Flix, per tal d'aprofitar l'aigua del riu per al procés de fabricació de productes químics: clorur de calci i altres derivats del clor o de la sosa càustica. Tanmateix, el sector primari continuava essent l'activitat econòmica predominant en aquestes comarques.

Amb l'arribada de la filloxera a les vinyes occitanes, el preu del vi va augmentar de forma molt important, el que va provocar una gran empenta econòmica d'aquestes comarques. Si l'any 1864 el preu de $100 \mathrm{~kg}$ de vi era de 18-20 pessetes, el 1876 pujava a $20-35$, el $1879-80$ a $30-50$, el 1882 a 40 i el 1885 a 50.

L'any 1887, la població del Priorat era de 27.461 habitants. Però, l'any 1893 la plaga va arribar a la comarca. L'any 1900 , el Priorat havia perdut 5.000 habitants. L'any 1890 el preu dels $100 \mathrm{~kg}$ de vi era de 20 pessetes $^{13}$. La "malaltia de la vinya" significar un estrall a la comarca que s'arrossegà durant dècades ${ }^{14}$.

Des de llavors, la població de la comarca no ha parat de reduir-se, arribant el 1998 al seu mínim històric, 9.119 habitants. Si a finals del segle XIX la densitat de la població era de $55,08 \mathrm{hab} / \mathrm{km}^{2}$, mentre que al conjunt de Catalunya era $40,77 \mathrm{hab} / \mathrm{km}^{2}$, a finals del XX era de $18,5 \mathrm{hab} / \mathrm{km}^{2}$, per 191,5 al territori autonòmic $^{15}$. De 1900 a 1970 el Priorat perd el $45 \%$ de la seva població, la qual va a treballar a les zones urbanes més properes o a Barcelona.

Cal tenir en compte, que "la reposició de la producció vitícola serà lenta, no es plantejaran alternatives i el Priorat s'anirà despoblant i descapitalitzant, la qual cosa serà el preu del monocultiu agrícola i de l'excessiva especialització

\footnotetext{
12 Per una aproximació històrica d'aquesta fàbrica, podeu consultar AAVV., Centenario de "la fábrica". De la sociedad electro-química de Flix a Erkimia (1897-1997), Erkimia. Flix, 1997 (1a edició).

13 Dades extretes de Josep Iglésies, Les minves del cultiu i de la població a la comarca del Priorat, Rafael Dalmau Editors. Barcelona, 1975 (1a edició).

${ }^{14}$ Sobre l'impacte de la fil-loxera en l'economia prioratina, podeu consultar Romà Perpiñà i Grau, La crisi del Priorat, Edicions del Centre de Lectura. Reus, 1932 (1a edició).

${ }^{15}$ Dades extretes de l'Institut d'Estadística de la Generalitat de Catalunya.
} 
econòmica [...] la gent del Priorat no sembla capaç de reaccionar, la renda disminueix i el mecanisme de sortida és l'emigració cap als nuclis industrials" 16 . A la Ribera d'Ebre la filloxera no va causar tants estralls econòmics i demogràfics com al Priorat, a causa del pes menor de la vinya en el conjunt de l'activitat primària de la comarca. Ans al contrari, els anys de la filloxera la població va créixer lleugerament: de 27.628 l'any 1887 a 29.891 l'any 1900. I, va seguir creixent fins a 1920 (30.349 habitants).

Serà a partir de 1960 (27.647 habitants) que la població només ha fet que decréixer de forma progressiva, especialment durant aquesta dècada (24.774 habitants el 1970) i la dels 80 (22.994 habitants el 1992), i el 2018 es quedava en 21.964 habitants $^{17}$. En poc més de seixanta anys, de 1920 a 1986, la Ribera d'Ebre va perdre el $22,7 \%$ de la seva població, i "ni els llunyans anys de la postguerra ni la més recent reactivació econòmica generada per la CN Ascó durant els anys setanta i primers vuitanta no ha aconseguit canviar el signe d'aquesta tendència regressiva ni tan sols estabilitzar la població"18.

Així doncs, al llarg del segle XX i especialment a partir dels anys 60 amb el Plan de Estabilización de 1959 i els Planes de Desarrollo (1964-1967, 19681971 i 1972-1975), es produirà un procés d'inversió de capital públic i estranger que desenvoluparà la indústria a les comarques litorals catalanes, i aquestes comarques d'interior -com la gran majoria d'elles d'arreu de Catalunyacomençaran un procés d'èxode rural que implicaran un important despoblament i envelliment de la població.

Tanmateix, a la Ribera d'Ebre a diferència del Priorat, l'hegemonia del sector primari es veurà desplaçat per la inversió en la indústria. La planta de finals del XIX a Flix anà ampliant-se i creixent al llarg del segle XX, amb la construcció de la presa als anys 40 i l'ampliació de les línies de producció per a fabricar nous productes químics: detergents, adhesius, resines polimèriques... L'any 1960 l'empresa disposava de 1.500 treballadors, i fins als anys 80 , l'empresa no parà de créixer en volum de producció.

\footnotetext{
16 Joaquim Margalef Llebaria i Joan Tasias Valls, El Priorat, anàlisi d'una crisi productiva, Caixa d'Estalvis de Catalunya. Barcelona, 1985 (1a edició), p. 63.

${ }_{17}$ Dades extretes de l'Institut d'Estadística de la Generalitat de Catalunya.

${ }^{18}$ AAVV., Diagnosi comarcal de la Ribera d'Ebre, vol. II, Generalitat de Catalunya. Tarragona, 1989 (1a edició), p. 704.
} 
També als anys 60 s'acaba la construcció de l'embassament de Riba-roja d'Ebre promoguda per ENHER per a produir energia hidroelèctrica per una potència de $263 \mathrm{MW}$. Una obra que va significar la inundació del poble miner de Mequinensa (el Baix Cinca) i el de Faió (el Matarranya) ${ }^{19}$.

Però serà a la dècada dels 80 , quan s'iniciarà la implantació d'indústries extractives que configuren la realitat actual de la comarca. Els anys 1984 i 1986 és quan entren en funcionament les dues centrals nuclears d'Ascó ${ }^{20}$, que convertirà la Ribera d'Ebre amb la comarca amb un major PIB de tot Catalunya. Si l'any 1973 la renda per càpita de la comarca era de 68.069 pessetes per habitant, mentre que la mitjana de Catalunya era de 107.102, l'any 1979 (en ple procés de construcció de les dues centrals nuclears) la renda per càpita a la Ribera d'Ebre havia pujat a 327.624 pessetes, mentre que la mitjana catalana era de 324.137 pessetes $^{21}$.

Si prèviament a la construcció de les dues centrals nuclears d'Ascó la indústria (bàsicament les fàbriques de Flix) ocupaven el 18,9\% de la població i el sector primari ocupava al 39,9\% dels treballadors i treballadores, l'any 1981 el sector primari es reduïa al $22,3 \%$ de la població activa i la indústria i la construcció (encara no s'havien posat en marxa les centrals nuclears, sinó que estaven en plena construcció) sumaven el $55 \%$ de la mà d'obra comarcal ${ }^{22}$.

En concret, l'ocupació de la CN Ascó I i Il de 1972 (quan comença a construirse) a 1984 (quan es posa en marxa la CN Ascó I) va passar de 15 persones a 1.400. Tanmateix, el moment de màxima ocupació va ser de 5.700 persones el 1982.

I, és que "amb l'acabament de les obres de construcció (que el 1984 pràcticament ja no ocupaven personal), el nombre d'ocupats -en muntatge i explotació- va davallar notablement: els 4.721 ocupats el 31 de gener de 1983 es van reduir uns 1.000 (550 de muntatge i 450 d'explotació) a la fi del març de

\footnotetext{
${ }^{19}$ Sobre l'impacte de la construcció de l'embassament de Riba-roja als municipis de la Franja podeu llegir Jesús Moncada, Camí de Sirga, Edicions 62. Barcelona, 1988 (1a edició).

20 Per una aproximació al conflicte que va suscitar la construcció de les centrals nuclears a Ascó, podeu consultar Xavier Garcia, La primera dècada de lluita antinuclear a Catalunya (1970-1980), Arxiu Comarcal del Priorat. Torroja, 2008 (1a edició).

${ }_{21}$ Dades extretes de Jesús Sorribes i Monserrat i Josep-Joan Grau i Foch, La Ribera d'Ebre. Transformacions sòcio-econòmiques i perspectives de futur, Caixa de Catalunya. Barcelona, 1989 (1a edició).

22 Dades extretes de AAVV., Diagnosi comarcal de la Ribera d'Ebre, vol. I, Generalitat de Catalunya. Tarragona, 1989 (1a edició).
} 
1985. Aquesta reducció de plantilla afecta particularment la mà d'obra de la comarca, ja que de les tres especialitats del personal ocupat en l'obra - obra civil, muntatges mecànics i muntatges elèctrics -, va ser l'obra civil o construcció (a càrrec de Nucea, amb un percentatge elevat de peonatge) la que va ocupar més mà d'obra autòctona, mentre que les empreses de muntatge, d'obrers més especialitzats, el contingut d'autòctons no era gaire elevat. Un cop engegada la central, les necessitats de mà d'obra es redueixen al personal d'explotació, el qual representa al voltant de 500/600 persones fixes"23.

Alhora, la instal-lació de les centrals nuclears generaran un augment exponencial dels ingressos de l'ajuntament del municipi que l'acull. Si l'any 1983 els ingressos de l'Ajuntament d'Ascó eren de 45,3 milions de pessetes, l'any 1984 (amb la posada en marxa de la CN Ascó I) ascendeixen a 257,3 milions de pessetes. Una dinàmica que augmentarà amb la posada en marxa de la CN Ascó $1{ }^{24}$.

Cal afegir també, que al final d'aquesta dècada es quan es posa en funcionament el transvasament d'aigua de l'Ebre cap al Camp de Tarragona i el Penedès $^{25}$, per tal de poder resoldre les dificultats de proveïment d'aigua d'aquelles comarques, que havien multiplicat la seva població en les darreres dècades gràcies a la indústria i al turisme 26 .

Després de la dècada nuclear, va arribar la dècada dels abocadors, quan l'any 1988 es va construir l'abocador del Racó de la Pubilla, al mateix municipi de Flix, per tal d'abocar-hi els fangs que generava la fàbrica d'Ercros. Però, cal destacar especialment, l'obertura de l'abocador de Tivissa l'any 1994, que tracta els residus domèstics de la Ribera d'Ebre, la Terra Alta i el Priorat, però que posteriorment també acollí els residus de la comarca del Baix Camp (durant el període estival en que la comarca multiplica la seva població per l'afluència del turisme) i de pobles del Baix Ebre, així com els industrials de totes les Terres de l'Ebre i gran part de les comarques del Camp. Posteriorment, l'any 2004, es va inaugurar un nou abocador de gestió privada

\footnotetext{
23 Jesús Sorribes i Monserrat i Josep-Joan Grau i Foch, La Ribera d'Ebre... op. cit., p. 182.

${ }^{24}$ Dades extretes de Jesús Sorribes i Monserrat i Josep-Joan Grau i Foch, La Ribera d'Ebre... op. cit..

${ }^{25}$ Ley 18/1981, de 1 de julio, sobre actuaciones en materia de aguas en Tarragona, Boletín Oficial del Estado, núm. 165, d'11 de juliol de 1981.

${ }_{26}$ Per una aproximació al "minitransvasament", podeu consultar Tomàs Carot Giner, 25 anys d'aigua, Consorci d'Aigües de Tarragona. Tarragona, 2014 (1a edició).
} 
al mateix municipi per a una capacitat de 3,3 milions de metres cúbics, i que acull residus domèstics $\mathrm{i}$ industrials de fins a 21 comarques de la comunitat autònoma ${ }^{27}$.

La primera dècada del segle XXI és la dècada dels projectes fracassats a la comarca. L'any 2001 l'empresa multinacional Enron volia construir una Central Tèrmica de Cicle Combinat de 1.600 MW a Móra la Nova, però va topar amb l'oposició ciutadana i política, i a més, l'empresa va fer fallida el mateix any ${ }^{28}$. L'any següent va haver-hi una temptativa, en aquesta ocasió amb capital privat, per a construir un abocador a Móra d'Ebre, però la pressió ciutadana ho va evitar. Així com també de construir-ne un altre a Tivissa, però els ajuntaments s'hi van oposar.

El 2003, després del fracàs de l'experiència d'Enron, la Generalitat va anunciar l'interès d'Iberdrola per a construir una Central Tèrmica de Cicle Combinat de 800 MW a Riba-roja d'Ebre, al·legant que els anys anteriors Reus i Tarragona havien patit talls en el subministrament elèctric durant la temporada d'estiu, però finalment, tampoc es va dur a terme la seva construcció ${ }^{29}$. De fet, l'any següent s'iniciava la construcció d'una Central Tèrmica de Cicle Combinat de la mateixa potència al municipi de Vandellòs i l'Hospitalet de l'Infant (el Baix Camp), que suplia la motivació del projecte a la Ribera.

L'any 2004 el govern espanyol del PSOE també derogava el Pla Hidrològic Nacional que havia aprovat el govern del PP i que havia generat una mobilització ciutadana contestatària sense precedents a les Terres de l'Ebre. El PHN preveia entre d'altres mesures el transvasament d'aigua de l'Ebre cap als territoris del llevant peninsular així com la interconnexió de l'Ebre amb Aigües Ter-Llobregat, a partir de les canonades del CAT, conegudes com a

\footnotetext{
${ }^{27}$ Sobre aquest projecte, podeu consultar Àlex Tarroja (dir.), Anuari Territorial de Catalunya 2004, Societat Catalana d'Ordenació del Territori. Barcelona, 2005 (1a edició).

28 L'enfonsament de la setena empresa més gran dels Estats Units ha estat considerada una de les estafes financers més importants abans de la crisi econòmica de 2008. Entre l'extensa bibliografia es pot consultar, per exemple, Malcolm S. Salter, Innovation corrupted: The origins and legacy of Enron's collapse, Harvard University Press. Cambridge, 2008 (1a edició) o Mimi Swartz i Sherron Watkins, Power failure: the inside story of the collapse of Enron, Broadway Business. Nova York, 2004 (1a edició).

${ }^{29}$ Més informació sobre aquests projectes a Juli Estaban i Àlex Tarroja (dirs.), Anuari territorial de Catalunya 2003, Societat Catalana d'Ordenació del Territori. Barcelona, 2004 (1a edició).
} 
"minitransvasament". Aquesta darrera proposta no va quedar del tot tancada després de la derogació del $\mathrm{PHN}^{30}$.

El mateix any, es fa públic un estudi que demostrava que l'activitat de l'empresa Ercros havia provocat la contaminació amb residus químics i radioactius de l'embassament del municipi que es va construir -com ja hem ditprecisament per afavorir l'activitat de l'empresa.

L'alarma social generada per aquest informe va provocar que el govern espanyol creés una comissió de seguiment d'aquesta problemàtica i iniciés un projecte de descontaminació, que segons sentència judicial, havia de pagar l'empresa contaminant.

Per altra banda, la primera dècada del segle XX també està protagonitzada per incidents constants a les dues centrals nuclears d'Ascó, que fins i tot provoquen l'aturada de la seva activitat en diferents períodes. Només de 2004 a 2006, per exemple, la CN Ascó I va patir disset incidències i la d'Ascó II catorze, ocupant el primer i tercer lloc respectivament en rànquing d'incidències a nivell estatal. A més, cal destacar l'incident de 2007 de la CN Ascó I que va provocar la fuga de partícules radioactives, i que un any després segons la pròpia Associació Nuclear Ascó Vandellòs, encara es detectaven aquestes partícules a l'exterior de la planta de producció ${ }^{31}$.

Però si hi ha un projecte fracassat durant aquesta dècada que provocà una important lluita a la Ribera (més enllà del PHN que fou al conjunt de les Terres de l'Ebre) fou la candidatura d'Ascó per acollir un cementiri nuclear al municipi, on hi anessin a parar els residus de les diferents centrals nuclears d'arreu de l'Estat espanyol, calculats per volum d'unes 7.000 tones aproximadament.

L'anunci d'aquest projecte cap a l'any 2005, davant la necessitat de garantir la seguretat dels residus nuclears de la CN Vandellòs I que es trobava en procés de desmantellament del seu incendi que en va provocar el tancament, va fer sorgir la Coordinadora Anticementiri Nuclear de Catalunya, la qual va aconseguir que les institucions locals i supramunicipals es posicionessin en

\footnotetext{
${ }^{30}$ Arran de la lluita social contra el Pla Hidrològic Nacional, la Plataforma en Defensa de l'Ebre se fa seu el concepte de "Nova Cultura de l'Aigua" teoritzat a Francisco Javier Martínez Gil, La nueva cultura del agua en España, Bakeaz. Bilbao, 1997 (1a edició).

31 Margarida Castañer (dir.), Anuari Territorial de Catalunya 2008, Societat Catalana d'Ordenació del Territori. Barcelona, 2009 (1a edició).
} 
contra d'aquest projecte, i que fins i tot el Parlament de Catalunya també s'hi oposés ${ }^{32}$.

Aquesta oposició institucional i les diferents mobilitzacions ciutadanes, segurament devien ser un factor que provocà que el govern espanyol decidís l'any 2011 que el Magatzem Temporal Centralitzat de residus nuclears s'ubiqués en un altre indret de l'Estat.

Després de la dècada dels projectes fracassats la present, vindrà protagonitzada per la implantació de parcs eòlics ${ }^{33}$. L'any 2002 la Generalitat aprova el Mapa d'implantació ambiental de l'energia eòlica, en el que establia les zones on es podien instal·lar centrals de producció energètica d'aquest tipus $^{34}$.

Aquest decret, i els successius i complementaris, permeteren la instal-lació de dues centrals eòliques a la comarca: l'any 2011 la central del Coll de la Garganta - entre la Torre de l'Espanyol i el Molar (el Priorat) - que allotja 13 aerogeneradors amb una potència elèctirca instal-lada de 21,71 MW d'electricitat; i l'any 2012, la central de Barbers, a Ascó, que disposa de 12 aerogeneradors amb una potència elèctrica instal-lada de $30 \mathrm{MW}^{35}$.

Com hem vist fins ara, doncs, l'estructura productiva del Priorat i la Ribera d'Ebre ha evolucionat com a comarca perifèrica amb un model de desenvolupament de caràcter dependent de les comarques centrals catalanes (Àrea Metropolitana de Barcelona i Reus-Tarragona).

Per una banda, el Priorat és una comarca purament agrícola, tot i que l'any 2000 es comptabilitzaven fins a 16 projectes de parcs eòlics que comportaven la instal-lació de 300 aerogeneradors amb una potència elèctrica instal·lada de 392,7 MW, que finalment 14 no es van acabar portant a la pràctica.

L'activitat primària representava el 26,78\% del total del PIB l'any 1991, mentre que a Catalunya representava el 2,15\%. La Construcció al Priorat representava

32 Per a més informació sobre aquest projecte podeu consultar Margarida Castañer (dir.), Anuari Territorial de Catalunya 2010, Societat Catalana d'Ordenació del Territori. Barcelona, 2011 (1a edició).

${ }^{33}$ Per una anàlisi sobre la implantació de l'energia eòlica a Catalunya, podeu consultar Sergi Saladié Gil, Conflicte entre el paisatge i l'energia eòlica. El cas de les comarques meridionals de Catalunya, Pagès Editors. Lleida, 2018 (1a edició).

34 Decret 174/2002, d'11 de juny, regulador de la implantació de l'energia eòlica a Catalunya. Diari Oficial de la Generalitat de Catalunya, núm. 3664, 26 de juny de 2002.

35 Informació extreta del Visor Ambiental de Parcs Eòlics del Departament de Territori i Sostenibilitat de la Generalitat de Catalunya <http://www.geolocal.cat/geoLocal/visorParcsEolics.jsp> [Darrera consulta 26 de març de 2019] 
un $11,24 \%$ del PIB per sobre del $8,25 \%$ del conjunt de Catalunya, mentre que la indústria (23,8\% Priorat i 34,06\% Catalunya) -el percentatge més baix de tot Catalunya- i els serveis (38,15\% Priorat i 55,53\% Catalunya) el Priorat estava per sota de la mitjana autonòmica.

El seu Producte Interior Brut l'any 1991 era de 46,4 milions d'euros, el que implica un número índex de 46 en relació a Catalunya que té el 100, és a dir, que el PIB del Priorat estava per sota de la meitat de la mitjana de Catalunya, essent la comarca amb el PIB més baix de tot Catalunya.

Com deia un estudiós de la comarca, a mitjans de la dècada dels 80: "I'anàlisi de la realitat comarcal difícilment pot fer que siguem optimistes sobre la situació econòmica i, àdhuc, sobre les possibilitats de futur"36.

La única obra que es va produir durant tot el segle al Priorat i que hipoteca encara avui en dia els recursos naturals de la comarca i el seu desenvolupament, és el transvasament d'aigua del riu Siurana a l'embassament de Riudecanyes que es va iniciar l'any 1950 per iniciativa de la Comunitat de Regants del Pantà de Riudecanyes, i que no permet que l'aigua del riu Siurana arribi al riu Ebre, del qual n'era afluent abans del transvasament i la construcció de l'embassament de Siurana l'any $1973^{37}$.

Per contra, la Ribera d'Ebre és una comarca on la indústria és el sector hegemònic en l'estructura productiva. L'any 1991 la indústria representava el $82,5 \%$ del PIB, el sector serveis el 12,07\%, l'agricultura el $3,63 \%$ i la construcció el $2,78 \%$.

El seu Producte Interior Brut l'any 1991 era de 537,9 milions d'euros, el que implicava un 1.159,27\% més de PIB en comparació al Priorat. La Ribera d'Ebre era de llarg, la comarca amb el PIB més alt de Catalunya. Sent el número índex del PIB a la comarca 219,2, quan a Catalunya era el 100. Per tant, el PIB de la Ribera d'Ebre era el doble de la mitjana de Catalunya ${ }^{38}$.

\footnotetext{
36 Joaquim Margalef Llebaria i Joan Tasias Valls, El Priorat, anàlisi d'una crisi productivaj... op. cit., p. 343.

37 Per una aproximació a aquest conflicte, podeu consultar l'informe "Incidència ambiental i social del transvasament Siurana-Riudecanyes (Tarragona), elaborat per Ecologistes en Acció, el GEPC i la Plataforma en Defensa de l'Ebre, que trobareu a: $<$ https://spip.ecologistasenaccion.org//MG/pdf/informe-trasvase-siurana-cat.pdf> [Darrera consulta 26 de març de 2019].

38 Dades extretes de l'Institut d'Estadística de la Generalitat de Catalunya.
} 
Tot i aquesta aparent abisme entre la riquesa que produeix la Ribera d'Ebre i el Priorat, cal fixar-se en l'impacte de la generació d'aquesta riquesa en les persones que viuen a la comarca.

Si ens centrem en aquesta qüestió, veurem que el Priorat era l'any 2002 la segona comarca de Catalunya amb un major percentatge de persones pobres sobre el total de la comarca a Catalunya (un 15,4\%). Però, si ens fixem amb la Ribera d'Ebre, veiem que tot $\mathrm{i}$ tenir el PIB més alt de Catalunya -que és el doble que la mitjana catalana- el percentatge de persones pobres sobre el total de la comarca ascendeix a 17,4\%, essent la comarca de Catalunya amb més gent pobre, i per tant també, amb una major desigualtat social ${ }^{39}$.

Així doncs, tal i com denunciaven els impulsors del moviment per la justícia ambiental, tot $i$ acollir un gran nombre d'activitats que malmeten el medi ambient, els beneficis d'aquestes indústries no reverteixen en la població de la comarca, sinó que enriqueixen les empreses que gestionen aquestes indústries que es troben ubicades en les comarques centrals de l'economia catalana, i la gran majoria d'elles, a la capital de l'Estat espanyol.

Com es trasllada aquest model de desenvolupament socioeconòmic des d'una perspectiva de la justícia ambiental? Tot i que el Priorat i la Ribera d'Ebre són exemples paradigmàtics d'economies perifèriques, el caràcter predominantment agrícola del primer $\mathrm{i}$ el caràcter industrial (indústries extractives i energètiques) del segon, van que la situació de justícia ambiental d'una i altra comarca, siguin també antagòniques.

El Priorat acull una important central eòlica - ubicada a Pradell de la Teixeta i a la Torre de la Fontaubella, tot $\mathrm{i}$ que també repartida entre Colldejou $\mathrm{i}$ L'Argentera (el Baix Camp) - amb una potència elèctrica instal-lada de 30,85 MW d'energia a partir de 91 aerogeneradors i part dels seus recursos hídrics són transvasats al Baix Camp. Com veurem en el proper capítol, ja no acull cap altre centre de producció energètica a la comarca.

La Ribera d'Ebre, com ja hem vist al llarg del present capítol, acumula un important abocador de residus, una central hidroelèctrica, dues centrals eòliques, dues centrals nuclears que a la primera dècada del segle XX han

\footnotetext{
${ }^{39}$ Dades extretes de Sergi Saladié Gil, op. cit., p. 64.
} 
presentat reiterats incidents $\mathrm{i}$, fins $\mathrm{i}$ tot la fuga de partícules radioactives, i una fàbrica electroquímica que ha contaminat l'embassament i els sòls de Flix.

Podem afirmar sense cap mena de dubte, doncs, que l'important excedent d'energia que produeix la Ribera d'Ebre per alimentar les necessitats de les comarques centrals de Catalunya, que en són clarament deficitàries, demostra no sols el caràcter perifèric de l'economia de la comarca, sinó que en termes de justícia ambiental és la comarca més perjudicada de tot Catalunya. Una situació que s'agreuja encara més, si tenim en compte la manca d'informació sobre els efectes reals de la contaminació de l'embassament i els sòls de Flix per part de la fàbrica electroquímica.

En canvi, el Priorat, tot i presentar també un marc característic d'una economia perifèrica, presenta una situació antagònica des de la perspectiva de la justícia ambiental, ja que no compte amb la presència d'indústries contaminants, abocadors o d'altres indústries que provoquin efectes negatius externs en el medi ambient.

\section{LA CONSTRUCCIÓ DE DOS MODELS DE DESENVOLUPAMENT ANTAGÒNICS}

Com hem vist en el capítol anterior, l'evolució demogràfica del Priorat i la Ribera d'Ebre és negativa. En el cas de la primera comarca, la més negativa del conjunt de Catalunya. En el cas de la segona, ho és malgrat la gran presència d'indústries de gran envergadura a la comarca.

Així doncs, el desplaçament de l'activitat primària per part de la indústria, no ha representat un revulsiu per a la comarca, sinó que no ha pogut ni frenar l'èxode cap a les comarques centrals del "sistema-món català", tot i que l'impacte demogràfic no ha estat tant important com al Priorat, que cal recordar que és qui malauradament encapçala el rànquing de despoblament a Catalunya.

Si ens fixem en l'evolució de la població en les dues darreres dècades, el comportament de la població segueix la mateixa tendència tant en una comarca com en l'altre. De 1998 a 2018, la Ribera d'Ebre ha mantingut la seva població (ha passat de 22.265 habitants a 21.964) i el Priorat, fins i tot, l'ha augmentat (ha passat de 9.119 habitants a 9.296), tot i la davallada des de l'inici de la 
present dècada comuna a tot Catalunya, a causa de la crisi econòmica de 2008.

La comarca del Priorat, doncs, ha aconseguit frenar en les darreres dues dècades l'ensolcida poblacional que feia més d'un segle que es produïa a la comarca de forma progressiva, tot i que encara no l'ha aconseguida revertir. I, a més, ho ha fet -com veurem a continuació- apostant per un model de desenvolupament socioeconòmic pioner a Catalunya, que representa una alternativa al model industrialitzador i perifèric de la Ribera d'Ebre.

Com hem vist, la Ribera ha mantingut fins al present un model de desenvolupament socioeconòmic que l'ha perpetuat com una economia perifèrica i dependent, que no ha estat capaç d'aportar riquesa a la comarca, i que a més, es produeix en uns termes de profunda injustícia des de la perspectiva de justícia ambiental.

Lluny de revertir aquest model, en els darrers anys, aquest continua aprofundint-se. Així ho demostren quatre qüestions concretes que reprodueixen el model de desenvolupament del llarg del segle XX: nuclears, residus contaminants, abocadors i centrals eòliques.

Pel que fa al primer, l'any 2011 l'Estat espanyol va renovar per deu any més la Ilicència d'explotació de les centrals nuclears d'Ascó I i II, tot i-com ja hem vistes produïssin incidents constants en el funcionament d'aquestes dues centrals ${ }^{40}$.

El passat mes de febrer de 2019 el govern de l'Estat espanyol va pactar amb les empreses elèctriques de l'IBEX35 que exploten les centrals nuclears (Iberdrola i Endesa) l'allargament de la vida de disseny (25-30 anys) de les centrals nuclears. En el cas d'Ascó I fins al 2029 (47 anys) i, en el cas d'Ascó II, fins al 2030 (45 anys) ${ }^{41}$.

40 Orden ITC/3372/2011, de 22 de septiembre, por la que se concede la renovación de la autorización de explotación de la central nuclear Ascó I, Boletín Oficial del Estado, núm. 296, de 9 de desembre de 2011 i Orden ITC/3373/2011, de 22 de septiembre, por la que se concede la renovación de la autorización de explotación de la central nuclear Ascó II, Boletín Oficial del Estado, núm. 296, de 9 de desembre de 2011.

${ }^{41}$ Orden ETU/611/2017, de 21 de junio, por la que se modifica la Orden ITC/3373/2011, de 22 de septiembre por la que se concede la renovación de la autorización de explotación de la central nuclear Ascó II, Boletín Oficial del Estado, núm. 152, de 27 de juny de 2017 i Orden ETU/610/2017, de 21 de junio, por la que se modifica la Orden ITC/3372/2011, de 22 de septiembre por la que se concede la renovación de la autorización de explotación de la central nuclear Ascó I, Boletín Oficial del Estado, núm. 152, de 27 de juny de 2017. 
Tot i aquestes dates no siguin definitives, el que queda clar és que el tancament de les dues centrals nuclears es produirà tard o d'hora, i que per tant, l'impacte del tancament d'aquestes dues centrals en la població de la comarca pot tenir importants conseqüències que implicaran canvi estructurals a mig termini, que s'agreujaran un cop acabin les obres de desmantellament d'ambdues centrals.

Pel que fa a la segona qüestió, la paralització de la construcció del cementiri nuclear, provoca que encara no estigui definit què es farà amb els residus nuclears quan es produeixi el tancament de les dues centrals, una qüestió que ja s'ha vist amb el tancament de la CN Vandellòs I. De fet, les dues centrals d'Ascó, actualment, està emmagatzemant el combustible gastat a les mateixes instal-lacions, ja que les piscines estan plenes $^{42}$.

Però, a més, cal tenir en compte que l'any 2017 va tancar, després de més d'un segle de producció, la fàbrica d'ERCROS a Flix, ja que la tecnologia va quedar obsoleta i l'empresa no volia invertir-hi per complir amb la nova normativa ambiental ${ }^{43}$. Més enllà de les conseqüències socioeconòmiques, amb un darrer Expedient de Regulació d'Ocupació que ha afectat als 120 darrers treballadors que quedaven a la fàbrica, la principal problemàtica d'aquest tancament és la descontaminació del pantà de Flix.

Unes obres, que a més estan paralitzades des de l'octubre de 2015 per una investigació judicial de l'Audiencia Nacional espanyola per presumpta malversació dels antics directius d'Acuamed (empresa propietat de FCC encarregada de dirigir les obres) per sobrecostos ficticis, precisament respecte aquesta obra, motiu pel qual no permeten a la nova concessionària que comenci a operar sobre el pantà. Un embassament, que presenta un important risc ambiental, ja que actualment, encara acumula més de 80.000 metres cúbics de llots tòxics abocats per l'antiga fàbrica ${ }^{44}$.

\footnotetext{
42 Informació extreta de: Ministerio de Industria, turismo y comercio, Sexto Plan General de Residuos Radioactivos, Ministerio de Industria, turismo y comercio. Madrid, 2006 (1a edició). 43 Ens referim a la Directiva 2010/75/UE del Parlamento europeo y del Consejo, de 24 de noviembre de 2010, sobre las emisiones industriales (prevención y control integrados de la contaminación), Diario Oficial de la Unión Europea, núm. 334, de 17 de desembre de 2010.

44 Noticia publicada el 6 de març de 2018 al diari El País: $<$ https://cat.elpais.com/cat/2018/03/06/catalunya/1520294363_824927.html> [Darrera consulta 27 de març de 2019]
} 
Tal i com ha demostrat un estudi ${ }^{45}$, el cost de descontaminació de Flix seria superior als càlculs realitzats fins ara, ja que més enllà de la contaminació del pantà, també cal comptar els sòls on estava emplaçada la fàbrica, el que tindria un cost de descontaminació aproximat d'entre 400 i 500 milions d'euros. Una despesa que l'empresa no assumeix i que la sentència de l'Audiència Provincial de Tarragona de 2007 no contempla ${ }^{46}$.

Sobre la tercera qüestió, a principis d'aquest any s'ha tornat a produir un debat sobre la gestió dels residus arran de l'anunci de l'alcalde de Riba-roja d'Ebre d'acollir un nou abocador de residus.

A diferència de fa quinze anys quan es va plantejar la construcció d'un abocador a Tivissa, les institucions del territori s'han oposat frontalment a aquest projecte -a excepció òbviament de l'Ajuntament de Riba-roja- i s'ha constituït una plataforma ciutadana per oposar-s'hi.

Precisament, la Plataforma Ribera Digna s'ha fet seu el discurs de la justícia ambiental per tal d'oposar-se a aquest projecte, i partint de l'anàlisi que hem desenvolupat en el capítol anterior, en el seu manifest explicita que "No podem repetir la història de la Ribera d'Ebre en les darreres dècades, amb grans instal-lacions industrials i energètiques que han generat un enorme passiu ambiental, amb beneficis que es privatitzen i pèrdues que se sociabilitzen, hipotecant el territori i les futures generacions. La construcció d'un nou macro abocador o l'ampliació de l'existent només empitjoraria la situació" 47 .

Actualment, el govern de la Generalitat ha paralitzat temporalment aquest projecte. Tanmateix, aquest no ha quedat descartat definitivament. Per tant, i tenint en compte l'opinió favorable del projecte per part de l'alcalde del municipi -que a més és director dels Serveis Territorials de Territori i Sostenibilitat de la Generalitat de Catalunya a les Terres de l'Ebre- encara no s'ha escrit el final definitiu d'aquest projecte.

45 Ens referim a la tesi doctoral de Marta Pujadas Garriga, La creació d'un passiu ambiental a Catalunya. Història de la planta química de Flix al riu Ebre (1897-2013), Universitat Autònoma de Barcelona, 2015.

46 Ens referim a la sentència que obliga a l'empresa Ercros Industrial, SA a fer-se càrrec del cost de descontaminació del pantà de Flix, Tribunal Supremo (Sala segunda de lo Penal), STS 1012/2007, de 4 de desembre de 2007.

${ }^{47}$ Manifest de la Plataforma Ribera Digna, a:

$<$ https://plataformariberadigna.wordpress.com/manifest/> [Darrera consulta 26 de març de 2019] 
I, per últim, cal parlar dels projectes en tràmit de nous parcs eòlics. L'any 2012 el govern de la Generalitat va aprovar el mapa de zones de desenvolupament prioritari de parcs eòlics (ZDP) ${ }^{48}$, en el que s'estableixen sis zones amb una potència total de $589 \mathrm{MW}$.

Dos d'aquestes sis afecten la comarca de la Ribera d'Ebre: la ZDP V, amb 120 MW i que afecta el terme de Tivissa i la ZDP VI, amb 60MW i que afecta el terme municipal de Riba-roja d'Ebre.

En paral·lel, i d'acord amb el Decret 174/2002, d'11 de juny, regulador de la implantació de l'energia eòlica a Catalunya, actualment a la Direcció General de Polítiques Ambientals de la Generalitat de Catalunya hi ha en tràmit diversos projectes per a la seva autorització: el Parc Riba-roja, amb una potència de 49,9 MW repartits en 16 aerogeneradors als termes municipals de Riba-roja d'Ebre i Flix; el Parc Carabers, amb una potència de $50 \mathrm{MW}$ amb la instal-lació de 25 aerogeneradors al terme de Garcia; el Parc d'Ascó, amb una potència de 4,9 MW dividits en 3 aerogeneradors al terme d'Ascó; el Parc Ginestar, en el que s'instal-larien 3 aerogeneradors amb una potència instal-lada de $9 \mathrm{MW}$; el Parc La Bruixeta, amb 8 aerogeneradors i una potència energètica de $9 \mathrm{MW}$ als termes de la Torre de l'Espanyol i Vinebre; el Parc La Toa al terme de Tivissa, amb 11 aerogeneradors i una potència de $40 \mathrm{MW}$; el Parc Les Marrades al mateix terme municipal, també amb una potència de $40 \mathrm{MW}$ però amb 13 aerogeneradors; el Parc Les Vallfenoses, amb 10 aerogeneradors i una potència de $20 \mathrm{MW}$ al terme municipal de Flix; el Parc de la Punta de la Bruixeta, amb una potència de $9 \mathrm{MW}$ repartits en 6 aerogeneradors, als termes de la Torre de l'Espanyol i Vinebre; el Parc de la Serra del Rovelló, als mateixos termes municipals, amb la mateixa potència energètica instal-lada $i$ els mateixos aerogeneradors; el Parc de la Serra dels Abellons, amb la mateixa potència i aerogeneradors i als mateixos termes municipals; el Parc de Tivissa, amb 34,5 MW de potència, repartits en 41 aerogeneradors, al terme municipal

\footnotetext{
48 Acord GOV/120/2012, de 20 de novembre, pel qual s'aprova la determinació de les zones de desenvolupament prioritari (ZDP) de parcs eòlics, Diari Oficial de la Generalitat de Catalunya, núm. 6.263, de 28 de novembre de 2012.
} 
de Tivissa; i finalment, el Parc Vallplana, al mateix terme municipal, i amb una potència de $35 \mathrm{MW}$ i la instal-lació de 11 aerogeneradors ${ }^{49}$.

En resum doncs, actualment estan en tràmit les sol-licituds de diferents empreses de fora de la comarca per a construir nous parcs eòlics que implicarien la instal-lació de 159 aerogeneradors i afectaria al terme municipal de 9 municipis d'un total de 14 que en té la comarca. I una potència energètica instal-lada de 319,3 MW.

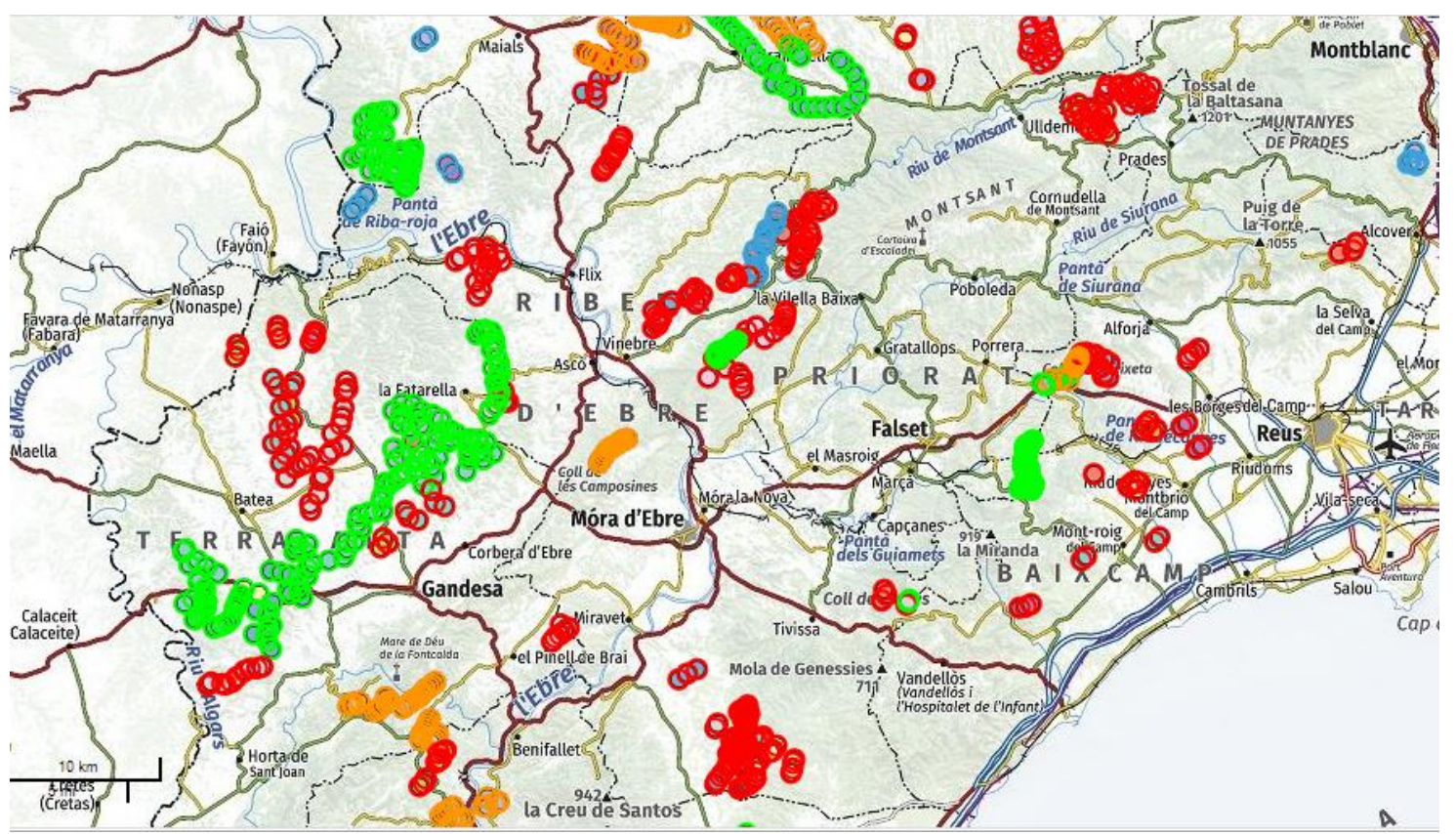

Font: Visor Ambiental de Parcs Eòlics de la Generalitat de Catalunya (en verd: parcs en servei. En vermell: parcs en tràmit. En taronja: parcs autoritzats)

Si tots aquests projectes s'arribessin a portar a terme, la comarca de la Ribera d'Ebre podria tenir instal-lada una potència energètica, abans del tancament de les centrals nuclears, de 371,01 MW d'energia eòlica que se sumarien als 2.059,7 MW d'energia nuclear i 200 MW d'energia hidroelèctrica. Més de 2.500 MW de potència energètica instal·lada, que encara farien més gran l'escletxa entre producció i consum energètic de la comarca i condemnarien la Ribera d'Ebre a ser la comarca amb una pitjor justícia ambiental de Catalunya.

49 Informació extreta del Visor Ambiental de Parcs Eòlics del Departament de Territori i Sostenibilitat de la Generalitat de Catalunya <http://www.geolocal.cat/geoLocal/visorParcsEolics.jsp> [Darrera consulta 26 de març de 2019] 
En resum, en l'actualitat i a curt termini, la Ribera d'Ebre no sols està revertint, sinó que està aprofundint en el seu model desenvolupament econòmic iniciat a finals del segle XIX, basat en una indústria extractiva, que genera grans beneficis per a les empreses explotadores de les centrals, però que no genera riquesa al territori i que més deixa un importantíssim deute ambiental.

A més, la data de caducitat de les dues centrals nuclears ubicades a Ascó, obliguen la comarca a buscar una alternativa econòmica per al seu futur postnuclear per tal d'evitar un èxode important de població que ja s'ha començat a notar amb els diferents EROs i el tancament definitiu de la fàbrica d'Ercros a Flix. El municipi ha passat de 4.208 habitants l'any 2000 a 3.491 el $2018^{50}$, just l'any que es va produir el seu tancament.

La dinàmica de les darreres dècades de la comarca del Priorat és l'antítesi d'aquest model. L'inici cal situar-lo a finals de la dècada dels 80 , a partir de l'arribada de viticultors de fora de la comarca ${ }^{51}$, que van aportar innovacions tècniques a la forma d'elaborar el vi, que a finals dels 90 i començaments del segle XXI han significat un revulsiu per a l'economia de la comarca.

Tanmateix, no cal oblidar, que si aquests viticultors forasters van poder importar nous coneixements va ser gràcies a la xarxa de cooperatives dels pobles de la comarca i dels pagesos que havien sobreviscut a l'èxode rural produït al llarg del segle ${ }^{52}$.

Així doncs, l'impuls econòmic no ha vingut per un canvi en el sector productiu predominant en l'estructura productiva de la comarca, ja que l'augment del sector terciari es deu a la indústria desenvolupada a partir del vi, i per tant, a partir de la potenciació del propi sector primari.

Cal destacar que l'any 1982 la superfície de conreu de la vinya a la comarca es situava en 7.663 hectàrees, quan l'any 1900 (ja havia causat estralls la fil-loxera) era de 20.855 hectàrees ${ }^{53}$.

\footnotetext{
50 Dades extretes de l'Institut d'Estadística de la Generalitat de Catalunya.

51 Per a més informació sobre aquests viticultors innovadors, podeu consultar Miquel Àngel Bové Sans, Innovació en indústries tradicions: la (r)evolució vitivinícola del Priorat com a cas d'èxit, Publicacions de la Universitat Rovira i Virgili. Tarragona, 2013 (1a edició).

52 Roser Vernet Anguera, De Priorat a prior(it)at, reapre(he)ndre el paisatge propi, a $<$ http://prioritat.org/wp-content/uploads/2014/07/article-canemas-.pdf> [Darrera consulta 27 de març de 2019]

${ }^{53}$ Dades extretes del llibre Josep Iglésies, op. cit.
} 
L'any 1990 la producció de vi als municipis inclosos dins la DO Priorat va ser de 5.000 hectolitres, el mínim històric, fins i tot a molta distància dels anys més durs de la fil-loxera, quan el 1910 es van produir 20.590 hectolitres $^{54}$.

Per tant, ens trobem davant d'un sector que es trobava en plena decadència a causa del poc valor afegit del producte en el mercat.

Si bé l'any 2015 el conreu de la vinya dins els termes de la DOQ Priorat només ocupava 1.916 hectàrees i a la DO Montsant 1.840 hectàrees, la producció era de 13.887 hectolitres i 46.128 hectolitres respectivament. Per tant, tot i l'important retrocés de la superfície cultivada l'augment de la productivitat d'aquestes terres, mitjançant un procés de creixement intensiu ha provocat un augment exponencial de la producció.

Si ens fixem en l'evolució de la producció en els darrers anys, trobem que la DOQ Priorat ha passat de produir 7.314 hectolitres la temporada 2010-2011 a produir-ne 14.610 la temporada 2015-2016. Per tant, en poc menys d'una dècada ha multiplicat per dos la producció de vi. Pel que fa a la DO Montsant, si la temporada 2010-2011 va produir 21.533, la temporada 2015-2016 en va produir 53.149.

Per tant, el creixement encara ha estat lleugerament major en comparació a la DOQ Priorat. Del total de 358.820 hectolitres de vi que es van produir al conjunt de Catalunya la temporada 2015-2016, el 19\% del vi ha estat produït al Priorat. Mentre que a la temporada 2010-2011, la producció prioratina només representava el $8,3 \%$ del total català. Aquestes xifres mostren, clarament, la importància cada cop major del vi del Priorat -en les seves dues denominacions d'origen- i l'important creixement del conreu de la vinya, i especialment de la producció vitivinícola a la comarca.

Tanmateix, el nombre de viticultors a la comarca ha descendit lleugerament en aquest període analitzat. Del 2010-2011 que hi havia 929 viticultors als territoris de la DO Montsant i 618 als municipis de la DOQ Priorat, s'ha passat al 20152016 a 800 viticultors a la DO Montsant i 574 a la DO Priorat, el que mostra una concentració de la producció en menys mans ${ }^{55}$.

\footnotetext{
54 Dades extretes del Departament de Política Territorial i Obres Publiques, El Priorat: anàlisi económica i possibilitats de desenvolupament, Generalitat de Catalunya. Barcelona, 1981 (1a edició).

55 Dades de l'Institut Català de la Vinya i el Vi aportades pels propis consells reguladors de les denominació d'origen respectives.
} 
Una altra dada rellevant, que reflecteix aquest augment de producció, és l'augment de vendes. Si la temporada $1999-2000$ es van vendre 10.517 hectolitres de vi de la DOQ Priorat, la temporada 2010-2011 s'en van vendre 22.549 hectolitres. Alhora, de totes aquestes vendes, si bé la temporada 19931994 només se n'exportava un $6,8 \%$ del total de la producció (poc més de 40.000 litres) per un valor de $1.460 €$, la temporada $2010-2011$ se'n va exportar un 46,2\% (1.041.000 litres) per un valor de 10.149.615€, arribant la temporada 2006-2007 a un màxim històric del 55,4\%.

Alhora, també és important de destacar que mentre la temporada 1993-1994 el preu del litre de vi exportat de la DOQ Priorat era de 3,64€, la temporada 20102011 era de $9,75 €$, tot $\mathrm{i}$ que el seu màxim es va situar la temporada 2001-2002 amb un preu de $13,03 €$ el litre ${ }^{56}$.

En el cas de la DO Montsant la quantitat de vi que s'exporta és menor proporcionalment respecte la DOQ Priorat. Durant la campanya 2015-2016 es va exportar un $28,9 \%$ de la producció de vi DO Montsant, mentre que de la DOQ Priorat se'n va exportar un $48,1 \%$.

El principal país d'exportació de la DO Montsant és els Estats Units d'Amèrica amb un $28,5 \%$ del total de les exportacions, el segueix Alemanya amb un $19,5 \%$, el Canadà amb un 8,3\%, Bèlgica amb un 5,4\% i Japó amb un 5,3\%. En canvi, pel que fa a les exportacions del vi DOQ Priorat, si bé el principal país importador també és els Estats Units amb un 21,6\%, el segueix Suïssa amb un $15,7 \%$, el Regne Unit amb un 12,8\%, Alemanya amb un 9,3\% i Bèlgica amb un $5 \%{ }^{57}$.

En resum, doncs, el procés de transformació del sector vitivinícola a la comarca del Priorat, no sols cal valorar-lo per l'augment de la producció, sinó per l'augment de la qualitat dels productes i per un model d'explotació intensiva, que ha estat capaç de trencar amb la dependència econòmica de les comarques centrals del país i ha estat capaç d'inserir-se en l'economia mundial amb uns productes del sector primari però amb un alt valor afegit, i que a més,

\footnotetext{
${ }^{56}$ Dades extretes de Miquel Ángel Bové Sans, op. cit.

57 Dades extretes de l'Informe, núm. 4, de desembre de 2017 de l'Observatori de la vinya, el vi i el cava de l'Institut Català de la Vinya i el Vi, publicat a: $<$ http://agricultura.gencat.cat/web/.content/de_departament/de02_estadistiques_observatoris/08 _observatoris_sectorials/02_observatori_vinya_vi_cava/fitxers_estatics/informes/2017_informe4 _definitiu.pdf $>$ [Darrera consulta 27 de març de 2019].
} 
no provoquen efectes externs negatius en el medi ambient, sinó que precisament aquest és un dels valors que conté el producte.

Però, tot i que el sector vitivinícola ha estat l'element que ha capgirat la situació de depressió econòmica i social que vivia la comarca en les dècades anteriors, aconseguint revertir la pèrdua de població (de 2001 a 2007 la població creix en un $6 \%{ }^{58}$ ), aquest ha produït quelcom més important des de la perspectiva de la justícia ambiental, que ha estat, un canvi de paradigma en el model de desenvolupament socioeconòmic de la comarca amb la seva relació amb el medi.

Aquest procés de reformulació del concepte de "creixement" i de "progrés" s'inicià en paral·lel al creixement exponencial de la producció del vi, durant la primera dècada del segle XXI, a partir de l'oposició de la comarca als projectes de construcció de centrals eòliques que l'afectaven.

L'any 1999 neix la Plataforma per la Defensa del Patrimoni Natural del Priorat, davant un allau de sol-licituds d'empreses per tal de construir centrals eòliques a la comarca, tot just quan ja s'havia construit el Parc Trucarfort, amb una potència de 29,85 MW repartits en 91 aerogeneradors als termes municipals de Pradell de la Teixeta i la Torre de la Fontaubella (el Priorat) i Colldejou i l'Argentera (el Baix Camp).

El manifest fundacional de la Plataforma "Manifest del Priorat sobre les centrals eòliques" 59 , posava l'accent en diferents arguments per tal d'oposar-se a la instal-lació de més parcs eòlics a la comarca.

Entre els més destacats: que la implantació dels parcs eòlics no perseguia la sostenibilitat territorial i la conservació dels espais naturals, sinó simplement aspectes merament econòmics i de rendibilitat; que l'estudi dels llocs on instal-lar les centrals no s'havien fet amb estudis detallats, ja que molts d'aquelles ubicacions es trobaven dins d'espais PEIN o d'important valor; una manca de planificació que promogué l'especulació de terrenys; la venda de falses expectatives a la població sobre els efectes positius de la instal-lació d'aquestes centrals en els municipis afectats; i l'impacte en el medi ambient.

\footnotetext{
${ }^{58}$ Dades extretes de l'Institut d'Estadística de la Generalitat de Catalunya.

59 Podeu consultar aquest document a <www.ub.edu/cres/sites/default/files/32_Manifest.doc> [Darrera consulta 27 de març de 2019].
} 
Però, especialment per l'interès d'aquest treball, cal reproduir íntegrament tres dels set punts d'aquest manifest:

4.- La integritat paisatgística i els valors naturals i faunístics de les nostres muntanyes, afavorits per la poca pressió antròpica que ha sofert el medi natural, han esdevingut el nostre principal actiu econòmic, i han configurat la imatge que ajuda a vendre el nostre vi arreu del món, que omple els establiments turístics, que atrau visitants d'arreu i que fa que artistes, pintors i fotògrafs vinguin a la comarca a la recerca d'un encant difícil de trobar a la Catalunya urbanitzada del segle XXI.

5.- L'aprovació dels projectes que autoritzen la instal-lació indiscriminada de centrals eòliques posa els nostres governants en la disjuntiva d'escollir els usos del territori, ateses les incompatibilitats de les centrals eòliques amb el turisme o el sector vinícola, ambdós fonamentats en la imatge d'un Priorat no urbanitzat ni alterat per l'acció depredadora de l'home. La instal-lació de centrals eòliques crea una quantitat irrisòria de llocs de treball, i en canvi altera greument els vertaders sectors econòmics de la comarca.

[...]

7.- La plataforma es posiciona a favor dels models de desenvolupament rural respectuosos amb l'entorn, que permetin un creixement sostenible del Priorat, i també a favor de promoure un consum racional de l'energia, aturant el dispendi innecessari. Recordem que la xarxa elèctrica espanyola produeix un excedent d'energia, fins $\mathrm{i}$ tot en els moments de màxima demanda, i que aquestes centrals eòliques no substituiran altres formes de produir energia més contaminants i perilloses (nuclears, tèrmiques, etc.).

Així doncs, no ens trobem sols davant d'un manifest d'una entitat ecologista que es limita -que no és poc- a oposar-se a uns projectes d'aquestes característiques per qüestions estrictament de caràcter ambiental, sinó que trobem una aposta decidida per un model de desenvolupament socioeconòmic a la comarca, que s'allunya del model d'economia perifèrica i dependent que caracteritza la Ribera d'Ebre basada en la implantació d'indústries extractives i contaminants, sinó que planteja un desenvolupament dels sectors productius amb respecte amb el medi ambient, entenent aquest com un recurs econòmic estructural d'aquest model. 
L'any 2001, quan encara tots aquests projectes de centrals eòliques encara no s'havien portat a terme, es va signar l'Acord comarcal per al desenvolupament de l'energia eòlica al Priorat ${ }^{60}$ entre els partits polítics CiU, PSC, FIC i ERC, sis alcaldes de la comarca, els dos consells reguladors de les DO (DO Montsant i DOQ Priorat) i la pròpia Plataforma per la Defensa del Patrimoni Natural del Priorat, que n'era la impulsora.

Aquest acord contemplava contribuir en la implantació de centrals eòliques a Catalunya per fomentar les energies renovables i contribuir en la producció elèctrica, però renunciant a tots els projectes que hi havia sobre la taula $i$ habilitant dos espais als municipis de Cabacés i Margalef, on tindrien menys efectes negatius sobre el paisatge de la comarca.

Com que aquest acord no tenia cap mena de validesa jurídica, l'any 2002 es va instal-lar el Parc del Mas de la Potra, entre el terme municipal de Pradell de la Teixeta i Duesaigües (el Baix Camp) i l'any 2003 es va crear el Parc del Collet dels Feixos, al terme de Duesaigües però visible des molts municipis del Priorat. Però, es va aconseguir frenar la proliferació de projectes d'instal·lació de centrals eòliques a la comarca.

Tanmateix, aquesta lluita no va ser tant fàcil. L'any 2004 els alcaldes de CiU de la comarca, que havien perdut el control del Consell Comarcal a mans d'ERC, van qüestionar l'Acord signat tres anys abans.

Aquell mateix any, l'Ajuntament del Molar va organitzar un referèndum, en el qual la ciutadania va decidir rescindir el seu suport a l'Acord comarcal. Aquest Consistori governat per $\mathrm{CiU}$ va fer un front comú amb alcaldes del mateix partit d'altres municipis del Priorat i la Ribera d'Ebre per tal d'acollir un parc eòlic de grans dimensions.

Davant d'aquest fet, el Consell Comarcal va fer arribar una carta al Conseller Salvador Milà, recordant-li els punts de l'Acord Comarcal i demanant que els respectés. Aquest, va respondre ratificant aquells acords com a punt de partida de la planificació de noves centrals a la comarca i va proposar que els beneficis d'aquestes revertissin en el conjunt de la comarca, i no sols en els municipis que les acollien.

60 Per comprendre la significació d'aquest acord en el marc del desenvolupament de centrals eòliques al conjunt de Catalunya, podeu consultar Sergi Saladié Gil, "Anàlisi del procés d'implantació de centrals eòliques a les comarques meridionals de Catalunya", en Revista de geografia, núm. 5, 2008. 
Com a resposta a aquestes declaracions es va organitzar un moviment ciutadà favorable a la instal-lació de centrals eòliques a la comarca, amb el nom d'Acció veïnal per l'energia eòlica, que s'oposaven al repartiment de rèdits econòmics entre el conjunt de la comarca, qüestionant la legitimitat de l'Acord comarcal i mostrant-se favorables a impulsar més parcs.

Tot i aquests conflictes entre ajuntaments i societat civil, cap altre projecte de construcció de parc eòlic s'ha implantat a la comarca tot i l'interès de diferents empreses per fer-ho, més enllà dels comentats més amunt ${ }^{61}$.

Però, com dèiem anteriorment, la lluita de la Plataforma no sols es limitava a exigir la no-instal-lació de centrals eòliques a la comarca, sinó que pretenia proposar un model de desenvolupament socioeconòmic alternatiu al que s'havia imposat a la resta de comarques perifèriques del país.

En aquest sentit, cal destacar l'aprovació per part del Consell Comarcal l'any 2004, amb el suport dels dos consells reguladors de les dominacions d'origen, de l'inici dels treballs per obtenir la Carta del Paisatge, una iniciativa pionera a Catalunya per tal d'analitzar les potencialitats de la comarca ${ }^{62}$.

Es tractava d'un "document de caràcter públic i de compromís a favor del paisatge, en què les parts signants es comprometen davant la societat a formar part d'un projecte col-lectiu, a treballar en conseqüència per assolir els compromisos signats i a desenvolupar les mesures i accions territorials, urbanístiques, agràries, de potenciació del patrimoni natural i cultural, turístiques, de custòdia del territori i de desenvolupament local, amb l'objectiu principal de dinamitzar els valors del lloc on s'arribi a consensuar un pacte a favor del paisatge" 63 .

L'any 2006 el Consell Comarcal del Priorat va aprovar el document informatiu de la Carta del Paisatge que va ser revisat per part de les administracions públiques de la comarca, així com entitats de la societat civil ${ }^{64}$.

\footnotetext{
61 Sobre l'Acord Comarcal per al desenvolupant de l'energia eòlica al Priorat, podeu consultar: Àlex Tarroja (dir.), op. cit.

62 La iniciativa era tan pionera que encara no existia cap llei que reconegués aquest instrument, la qual no arribar fins a la Llei $8 / 2005$, de 8 de juny, de protecció, gestió i ordenació del paisatge. Diari Oficial de la Generalitat de Catalunya, núm. 4.407, de 16 de juny de 2005.

63 Eduardo Soler i Albert Cortina (dirs.), Carta del paisatge del Priorat, Consell Comarcal del Priorat. Falset, 2012 (1a edició), p. 2.

${ }^{64}$ Àlex Tarroja, Margarida Castañer i Montserrat Mercadé (dirs.), Anuari Territorial de Catalunya 2006, Societat Catalana d'Ordenació del Territori. Barcelona, 2007 (1a edició).
} 
Tanmateix, els canvis normatius succeïts en diferents institucions en relació al paisatge, van provocar que el procés d'aprovació de la Carta de Paisatge s'aturés ${ }^{65}$. A més a més, la Generalitat de Catalunya havia iniciat la redacció de la Carta del Paisatge del Camp de Tarragona ${ }^{66}$, que s'acabaria publicant l'any 2010, i el Pla Territorial Parcial del Camp de Tarragona ${ }^{67}$, que també s'aprovaria aquell mateix any.

No serà fins l'any 2012, que finalment, es signarà el Pacte pel paisatge del Priorat, per part del conseller de Territori i Sostenibilitat, el president del Consell Comarcal, els alcaldes dels ajuntaments de 19 municipis de la comarca, els consells reguladors de les tres denominacions d'origen de la comarca (les dues del vi i la DO protegida Siurana d'oli), l'associació patronal PIMEC i l'associació Prioritat que va néixer l'any 2007 per donar suport a la candidatura del Priorat com a Patrimoni de la UNESCO.

Entre els diferents compromisos que conté aquest Pacte podríem destacar-ne, adequar el desenvolupament urbanístic a la integració paisatgística amb l'entorn; projectes d'embelliment dels nuclis urbans i valorització del patrimoni arquitectònic; millorar la xarxa de camins com a potencials itineraris per a contemplar el paisatge i millora de la xarxa de carreteres i els accessos als pobles amb respecte al territori; planificar les activitats econòmiques i les infraestructures de serveis en espais que minimitzin el seu impacte paisatgístic; potenciar l'activitat agrícola tradicional i introduint innovacions que garanteixin la subsistència del sector, la qualitat del producte i el respecte al territori; conservar i gestionar adequadament els recursos fluvials; manteniment dels boscos per prevenir els incendis forestals; socialitzar els continguts de la Carta del Paisatge entre el veïnat de la comarca per generar una nova consciència

\footnotetext{
${ }^{65}$ Ens referim, a més de la Llei 8/2005 ja mencionada anteriorment, al Decret 343/2006, de 190 de setembre, pel qual es desenvolupa la Llei $8 / 2005$, de 8 de juny, de protecció, gestió i ordenació del paisatge, i es regulen els estudis i informes d'impacte i integració paisatgística. Diari Oficial de la Generalitat de Catalunya, núm. 4.723, de 21 de setembre de 2006, 0 l'adhesió de l'Estat espanyol el 25 de setembre de 2006 al Conveni europeu del paisatge: Instrumento de ratificación del Convenio Europeo del Paisaje (número 176 del Consejo de Europa), hecho en Florencia el 20 de octubre de 2000. Boletín Oficial del Estado, núm. 31, de 5 de febrer de 2008.

66 Joan Nogué Font i Pere Sala Martí (coords.), Catàleg de paisatge del Camp de Tarragona, Generalitat de Catalunya. Barcelona, 2012 (1a edició).

${ }^{67}$ Acord GOV/4/2010, de 12 de gener, pel qual s'aprova definitivament el Pla territorial parcial del Camp de Tarragona. Diari Oficial de la Generalitat de Catalunya, núm. 5.559, de 3 de febrer de 2010.
} 
sobre el valor del paisatge; i, potenciar noves interpretacions multidisciplinàries sobre el paisatge per potenciar-ne el seu valor.

Per tal de fer una avaluació de la implementació d'aquest projecte i alhora dinamitzar-lo, es va crear una comissió de seguiment del paisatge del Priorat, formada per representants de les institucions públiques però també de la societat civil.

En paral·lel al llarg procés de redacció de la Carta del Paisatge, l'any 2006 la Plataforma per la Defensa del Patrimoni Natural del Priorat van organitzar les primeres Jornades "Priorat: Quin paisatge, quin futur?", conjuntament amb la Universitat Rovira i Virgili.

El motiu central d'aquestes jornades, era la motivació de la Plataforma per a impulsar una campanya per tal que el paisatge del Priorat fos declarat Patrimoni Mundial per la UNESCO.

Com a resultat d'aquestes jornades, la Plataforma va impulsar un procés de confluència amb d'altres sectors de la comarca i fundà l'any 2007 l'associació Prioritat ${ }^{68}$, per tal d'aconseguir aquest objectiu.

L'entitat la conformen tant persones a títol individual com entitats del territori, com ara les dues DOs vitivinícoles, Unió de Pagesos, el Consorci de la Serra de Llaberia, l'Associació per a la Restauració i el Turisme Rural al Priorat, Carrutxa... i es marca com a objectius impulsar i coordinar les actuacions necessàries del procés de candidatura a la Llista del Patrimoni Mundial; donar suport a les actuacions globals i sectorials encaminades al reconeixement dels valors patrimonials del paisatge cultural del Priorat, vetllar per la preservació d'aquests valors i per la gestió respectuosa d'aquest patrimoni compartit, i promoure i donar suport a activitats i propostes que ajudin a consolidar un model de desenvolupament que garanteixi aquests valors, en col-laboració amb totes les persones, entitats i institucions d'àmbit comarcal i d'altres àmbits, com a garantia d'un futur que permeti viure dignament al territori.

Fruit de la feina feta durant tots aquests anys entre la ciutadania, les institucions acadèmiques i les institucions públiques, el Ple del Parlament de Catalunya del dia 11 d'abril de 2012, va donar suport a la inscripció del Priorat com a paisatge cultural agrari de la muntanya mediterrània en la Llista del

68 Podeu consultar el web de l'entitat a www.prioritat.org [Darrera consulta 27 de març de 2019] 
patrimoni mundial de la UNESCO ${ }^{69}$. Al maig de 2013, la Generalitat va escollir aquesta candidatura per tal de traslladar-la a Madrid, on s'inscriurà al mes de novembre, per tal que sigui presentada davant la UNESCO ${ }^{70}$. A l'estiu de d'aquest any, la UNESCO ha de donar el seu veredicte de si inclou el paisatge del Priorat en aquesta llista del Patrimoni Mundial.

La candidatura del Priorat es concentra en quatre eixos: el paisatge agrari, el patrimoni immaterial, el paisatge rural i el patrimoni natural.

En paral-lel a aquest camí per aconseguir aquest reconeixement, Prioritat ha continuat la tasca en l'organització de jornades iniciada per la Plataforma, per tal de debatre sobre el model desenvolupament socioeconòmic de la comarca, relacionant-ho amb la pròpia candidatura a la UNESCO.

En aquest sentit, destaquen les jornades organitzades l'octubre de 2014 "Priorat: territori sostenible i turisme, claus de futur", en que s'ha plantejat la necessitat que el Priorat pugui obtenir la Carta Europea de Turisme Sostenible, amb l'objectiu de desenvolupar un Pla Turístic per a la comarca a cinc anys vista, que permeti adaptar i promoure l'oferta turística actual a criteris de sostenibilitat ambiental71.

Precisament un mes després, el Parc Natural del Montsant ha pres el lideratge perquè la comarca pugui obtenir aquesta Carta i n'està promovent la candidatura ${ }^{72}$. I, en paral-lel, Prioritat ha participat en aquests darrers anys en diferents jornades sobre la relació entre turisme sostenible i patrimoni mundial73.

Com podem veure, doncs, l'impuls d'un model de turisme d'acord amb un model socioeconòmic respectuós amb el medi ambient que ja s'inicià amb el sector primari, centra ara els esforços de les entitats del territori per tal de

69 Podeu trobar el document a <https://www.parlament.cat/web/activitatparlamentaria/declaracions-institucionals/index.html?p_format=D\&p_id=112376024> [Darrera consulta 27 de març de 2019].

70 Podeu consultar tota la informació sobre la candidatura a $<$ http://www.candidaturapriorat.org/>.

71 Podeu trobar un resum d'aquestes jornades a: < http://prioritat.org/jornada-priorat-territorisostenible-i-turisme-claus-de-futur/> [Darrera consulta 27 de març de 2019]

72 Podeu trobar tota la documentació sobre aquesta candidatura a: $<$ http://www.consensus.cat/ccpriorat/index.php?option=com_info\&ltemid=524> [Darrera consulta 27 de març de 2019]

73 Podeu consultar les diferents jornades en que han participat a $<$ http://prioritat.org/tag/jornades/> [Darrera consulta 27 de març de 2019] 
diversificar l'economia de la comarca seguint un mateix criteri de desenvolupament.

Un esforç de la societat civil que també es veu reflectit en el Pla Estratègic Comarcal de Desenvolupament Socioeconòmic Rural 2014-2020 que està elaborant el Consell Comarcal del Priorat ${ }^{74}$.

Una qüestió central pel futur del territori per evitar el "monocultiu", que ja va causar una profunda crisi d'un segle de durada a la comarca, arran de la fil-loxera. La diversificació de l'estructura productiva de la comarca és central per evitar que causes conjunturals internes o externes puguin produir un ensorrament de la represa del dinamisme socioeconòmic de la comarca.

Amb totes aquestes iniciatives, el Priorat s'ha convertit en una comarca pionera a Catalunya, que qüestiona el model de desenvolupament i progrés heretat de la revolució industrial del segle XIX, per repensar aquests esquemes de desenvolupament de cara al futur.

Fins al present, al conjunt de Catalunya, el concepte de desenvolupament 0 progrés s'ha entès com un procés evolutiu de creixement econòmic i acumulació de caràcter lineal potenciat per les innovacions tecnològiques i que parteix d'una triple jerarquia [la divisió vertical del treball (capital i treball), la divisió sexual del treball (home i dona) i la divisió horitzontal del treball (centre, semiperifèria i perifèria)].

No obstant, a partir de la dècada dels anys 80 , especialment a partir de l'anàlisi de les economies perifèriques del sistema-món, diferents economistes comencen a desenvolupar la teoria del desenvolupament endogen, com a crítica al model d'economia del creixement dominant ${ }^{75}$.

Però, serà a partir de la dècada dels 90 , que el concepte de "desenvolupament endogen" es començarà a desenvolupar des de la vessant acadèmica de l'economia i de les teories comunitaristes d'Amèrica Llatina ${ }^{76}$.

\footnotetext{
${ }^{74}$ Podeu consultar la versió electrònica a http://priorat.cat/actualitat/noticia/PECDR [Darrera consulta 27 de març de 2019]

${ }^{75}$ Ens referim a les obres de Paul M. Romer, "The origins of endogenous growth", en Journal of economic perspectives, vol. 8, núm. 1, 1994 o Robert Emerson Lucas, "On the mechanics of economic development", en Journal of Monetary Economics, núm. 22, 1988.

76 Ens referim a l'obra del grup universitari bolivià Comuna, on destaquen obres com les de Luis Tapia, Pensando la democracia geopolíticamente, CLACSO i Muela del Diablo Editores. La Paz, 2009 (1a edició), Álvaro García Linera, Democracia, Estado, Revolución: Antología de textos políticos, Txalaparta. Tafalla, 2016 (1a edició), o Raúl Prada, Subversiones indígenas, Muela del Diablo Editores. La Paz, 2008 (1a edició).
} 
El fonament bàsic d'aquest model de desenvolupament econòmic es centra en potenciar les capacitats internes d'una societat per tal d'aconseguir una economia productiva autònoma que intenti trencar amb l'estructura productiva que li imposa el sistema-món i en el que els sistemes productius estiguin en mans de la comunitat local i els beneficis reverteixin en aquesta.

Amb aquest objectiu, és primordial de potenciar el capital humà a través de la innovació i el coneixement i potenciar les externalitats positives de l'estructura productiva, tot aconseguint un equilibri amb el medi ambient, que faci possible un desenvolupament sostenible ${ }^{77}$.

Com hem vist al llarg d'aquest capítol, la comarca del Priorat, està intentant caminar en la definició de l'aplicació d'aquest nou model de desenvolupament a la comarca. Tanmateix, perquè aquest sigui viable, hi ha molts factors i molts agents que el poden condicionar. Però, la introducció dels criteris de justícia ambiental en aquest model de desenvolupament, converteix la comarca, amb un cas d'estudi rellevant i que pot esdevenir un exemple per aquelles comarques, com la Ribera d'Ebre, que encara mantenint el mateix model de desenvolupament productiu heretat del segle XIX i potenciat al llarg del XX.

Tot i aquests esforços de la comarca del Priorat, el seu PIB l'any 2015 era de 172,9 milions d'euros, el que suposa un $61,8 \%$ del PIB per habitant en comparació al conjunt de Catalunya. Mentre que a la Ribera el PIB era de 976,1 milions d'euros, el que suposa un $47,6 \%$ més en comparació al conjunt de Catalunya.

Però, un cop més, si analitzem la renda familiar disponible bruta per càpita del Priorat, aquesta es situa en $14.700 €$, que representen un $87,6 \%$ en comparació amb el conjunt de Catalunya, i a la Ribera d'Ebre és de $15.200 €$, que representen un $90,1 \%$ en comparació amb el conjunt de Catalunya ${ }^{78}$.

D'aquest contrast de xifres, podem inferir que: com ja hem vist en les dades de 1990, la Ribera d'Ebre tot $i$ tenir el major PIB de tot Catalunya, aquesta riquesa no reverteix amb els seus habitants que tenen uns ingressos menors de la mitjana; que tot $\mathrm{i}$ tenir dos models productius tant diferents, ambdues

\footnotetext{
77 Sobre la relació entre activitat económica i medi ambient, podeu llegir AAVV., Los límites del crecimiento, Fondo de Cultura Económica. Mèxic DF, 1972 (1a edició) o Mark Shucksmith, "Endogenous development, social capital and social inclusion: Perspectives from LEADER in the UK", en Sociologia Ruralis, núm. 40, 2002.

78 Dades extretes de l'Institut d'Estadística de la Generalitat de Catalunya.
} 
comarques tenen uns nivells de rendes molt similars, però les habitants de la Ribera han de conviure amb una situació de greu injustícia ambiental; i, que hi ha més justícia i equitat redistributiva al Priorat, en comparació a la Ribera d'Ebre, perquè la similitud de PIB per càpita i renda per càpita indica que la riquesa que es produeix a la comarca reverteix en els ingressos dels seus habitants, i no van a parar als balanços de guanys de les grans empreses extractives que fan benefici a la comarca.

\section{CONCLUSIONS}

Al llarg del present article hem pogut veure com el Priorat i la Ribera d'Ebre presenten les característiques típiques d'una economia perifèrica, en relació a les comarques centrals catalanes. Un procés que arrenca de finals del segle $\mathrm{XIX}$, però que al llarg del segle $\mathrm{XX}$, genera dos models antagònics de desenvolupament socioeconòmic entre ambdues comarques.

Mentre que el Priorat pateix una forta davallada poblacional i la seva economia continua monopolitzada per un sector primari amb un molt reduït valor afegit, a la Ribera d'Ebre es produeix una forta inversió econòmica en el sector industrial, però que tampoc és capaç de frenar la reducció de població i, que a més, no genera riquesa al territori, sinó que produeix un fort deute ambiental que a dia d'avui encara no està calculat en termes econòmics.

Amb l'entrada del nou segle, la Ribera d'Ebre ha intentat mantenir el mateix model de desenvolupament, en base a projectes de noves indústries extractives com ara abocadors i centrals de producció energètica. Tanmateix, l'evolució de disminució de població s'ha mantingut i les desigualtats socials s'han cronificat.

A més, el tancament de la fàbrica d'Ercros a Flix i el proper tancament de les dues centrals nuclears d'Ascó plantegen un important debat sobre el futur de la comarca, ja que aquesta pot veure davallar de forma dràstica la seva població activa en les properes dècades, així com una forta reducció dels ingressos per l'activitat industrial per part de les institucions públiques locals.

Tot i que aquesta delicada situació, de moment, no sembla que ni la societat civil ni les institucions públiques tinguin interès en iniciar aquest debat. Tanmateix, en el darrer any s'ha produït una aliança entre la societat civil i els 
càrrecs electes de la comarca, entorn a l'oposició al projecte de macroabocador de Riba-roja d'Ebre- que comença a plantejar uns arguments relacionats amb la justícia ambiental, més enllà dels merament ecologistes.

Per altra banda, al Priorat, amb l'explosió del sector vitivinícola durant la darrera dècada del segle XX, s'ha frenat el procés d'èxode comarcal cap a les comarques centrals. I, a més, aquest procés de desenvolupament econòmic s'ha vist acompanyat per una organització de la societat civil i un suport de les institucions públiques, que a partir de l'oposició als projectes de construcció de centrals eòliques a la comarca, s'ha convertit en un veritable promotor d'un model de desenvolupament endogen de l'economia comarcal.

Tanmateix, com ja hem vist amb l'Acord comarcal per al desenvolupament de l'energia eòlica al Priorat i amb el procés de redacció de la Carta del paisatge del Priorat, la legislació autonòmica i les seves polítiques territorials des de l'executiu, no protegeixen explícitament el model de desenvolupament socioeconòmic de la comarca, que fins i tot poden entrar en contradicció amb el Pla Estratègic Comarcal de Desenvolupament Socioeconòmic Rural 20142020.

Pel que fa a la vessant jurídica, això suposa una amenaça constant per al territori, ja que en funció de les competències governamentals, algunes empreses foranes podrien establir a la comarca activitats econòmiques que trenquessin amb el model de consens al territori.

Cal, doncs, traslladar el debat comarcal a les institucions autonòmiques, per tal que aquell model que s'ha definit entre tots $i$ totes tingui un recolzament legal que permeti poder-lo desenvolupar. I, fins i tot, que el model desenvolupat al Priorat pugui servir de base per a desenvolupar un pla de territorial de desenvolupament per aquelles comarques catalanes perifèriques que es troben en una situació similar a la prioratina, o que com la Ribera d'Ebre, es veuen obligades a plantejar-se el seu model de desenvolupament socioeconòmic.

Malauradament, el poc pes demogràfic del Priorat en el conjunt de Catalunya, provoca que aquesta experiència no tingui la rellevància que es mereix, i continuï essent una qüestió secundària.

El suport de la Generalitat a la candidatura del Priorat com a Patrimoni Mundial i l'arbitri en el conflicte per l'aigua del Pantà de Siurana - Riudecanyes, poden 
representar un punt d'inflexió. Tanmateix, és evident la necessitat de tota una producció legislativa en matèria ambiental de caràcter més profund que eviti una reversió en el model de desenvolupament iniciat per la comarca i en d'altres d'arreu de Catalunya.

I, pel que fa a la vessant executiva, el canvi de color a les institucions, ja siguin les locals, però especialment les autonòmiques, podrien posar en perill el model que la comarca ha anat construint en les darreres dècades a manca d'una legislació i una planificació territorial que blindi aquest model.

En aquest sentit, la importància del pes de partits polítics al Parlament que a la comarca no tenen ja no sols representació, sinó ni presència, o el pes demogràfic (i, per tant, electoral) en d'altres comarques veïnes de les forces hegemòniques a la comarca, poden perjudicar el procés iniciat al Priorat.

Anant més enllà, i tenint en compte la data de caducitat del model de desenvolupament socioeconòmic de la comarca de la Ribera d'Ebre, el Priorat pot esdevenir també un exemple de com des de la societat civil i les institucions es pot treballar plegats per debatre sobre quin és el model de desenvolupament que beneficia més a la població.

Actualment, hi ha l'exemple de la comarca veïna de la Terra Alta que ja ha obert aquest procés davant l'inici de nous tràmits de sol-licituds per a la construcció de nous parcs eòlics, que han despertat l'oposició d'ajuntaments, societat civil i el consell regulador de la DO.

Aquest canvi de conjuntura dels interessos econòmics d'aquestes comarques, on la darrera dècada hi ha hagut una important promoció del turisme rural afegeix un nou element en aquest debat, que pot provocar un punt d'inflexió en el model de desenvolupament de les comarques perifèriques catalanes pel que fa a la seva estructura productiva.

Per últim, cal posar de nou de relleu, la connexió entre model de desenvolupament socioeconòmic i justícia ambiental. Les dues comarques que hem utilitzat per a l'estudi d'aquest article ho posen de relleu: una mateixa situació perifèrica en relació al sistema econòmic, però amb dos models antagònics de desenvolupament de les estructures productives que generen per a la Ribera d'Ebre una gravíssima situació d'injustícia ambiental i per al Priorat una situació òptima de justícia ambiental, gràcies a l'organització de la 
societat civil, que ha aconseguit frenar els projectes d'economia extractiva i ha estat capdavantera a principis de segle en la defensa d'un model de desenvolupament basat en l'explotació sostenible dels seus recursos naturals.

\section{BIBLIOGRAFÍA}

\section{Obres generals i articles científics}

AAVV., Los límites del crecimiento, Fondo de Cultura Económica. Mèxic DF, 1972 (1a edició).

AAVV., Diagnosi comarcal de la Ribera d'Ebre, vol. I, Generalitat de Catalunya. Tarragona, 1989 (1a edició).

AAVV., Diagnosi comarcal de la Ribera d'Ebre, vol. II, Generalitat de Catalunya. Tarragona, 1989 (1a edició).

AAVV., Centenario de "la fábrica". De la sociedad electro-química de Flix a Erkimia (1897-1997), Erkimia. Flix, 1997 (1a edició).

Amin, Samir, El desarrollo desigual. Ensayo sobre las formaciones sociales del capitalismo periférico, Editorial Fontanella. Barcelona, 1975 (2a edició).

Decadencia y crisis del capitalismo actual, Editorial Zero. Madrid, 1978 (1a edició).

Arrighi, Giovanni, Caos y orden en el sistema-mundo moderno, Akal. Madrid, 2001 (1a edició).

Baran, Paul A., La economía política del crecimiento, Fondo de Cultura Económica. México DF, 1959 (4a edició).

Blomström, Magnus i Hettne, Björn, La teoría del desarrollo económico en transición, Fondo de Cultura Económica. México DF, 1990 (1a edició).

Bové Sans, Miquel Àngel, Innovació en indústries tradicions: la (r)evolució vitivinícola del Priorat com a cas d'èxit, Publicacions de la Universitat Rovira i Virgili. Tarragona, 2013 (1a edició).

Braudel, Fernand, Civilización material, economía y capitalismo, Alianza Editorial. Madrid, 1984 (1a edició en 3 volums).

Bullard, Robert D., "Dismantling Environmental Racism in the USA", en Local Environment, vol. 4, núm. 1, 1999.

Carot Giner, Tomàs, 25 anys d'aigua, Consorci d'Aigües de Tarragona. Tarragona, 2014 (1a edició). 
Castañer, Margarida (dir.), Anuari Territorial de Catalunya 2008, Societat Catalana d'Ordenació del Territori. Barcelona, 2009 (1a edició).

Anuari Territorial de Catalunya 2010, Societat Catalana d'Ordenació del Territori. Barcelona, 2011 (1a edició).

Chomsky, Noam, El Nuevo Ordre Mundial (y el viejo), Editorial Crítica. Madrid, 1996 (1a edició).

Departament de Política Territorial i Obres Publiques, El Priorat: anàlisi económica i possibilitats de desenvolupament, Generalitat de Catalunya. Barcelona, 1981 (1a edició).

Dos Santos, Theontonio, Imperialismo y dependencia, Ediciones Era. México DF, 1978 (1a edició).

Espinosa González, Adriana, "La justicia ambiental, hacia la igualdad en el disfrute del derecho a un medio ambiente sano", en Universitas. Revista de Filosofía, Derecho y Política, núm. 16, 2012.

Estaban, Juli i Tarroja, Àlex (dirs.), Anuari territorial de Catalunya 2003, Societat Catalana d'Ordenació del Territori. Barcelona, 2004 (1a edició).

Fontana, Josep, Cambio económico y actitudes políticas en la España del siglo XIX, Editorial Ariel. Barcelona, 1975 (1a edició).

Foreman, Christopher H., The promise and peril of environmental justice, Brookings Institution Press. Washington, 1998 (1a edició).

Garcia, Xavier, La primera dècada de Iluita antinuclear a Catalunya (19701980), Arxiu Comarcal del Priorat. Torroja, 2008 (1a edició).

García Linera, Álvaro, Democracia, Estado, Revolución: Antología de textos políticos, Txalaparta. Tafalla, 2016 (1a edició).

Gunder Frank, André, Capitalismo y subdesarrollo en América Latina, Siglo XXI Editores. México DF, 1976 (1a edició).

Iglésies, Josep, Les minves del cultiu i de la població a la comarca del Priorat, Rafael Dalmau Editors. Barcelona, 1975 (1a edició).

Izard, Miquel, Manufactureros, industriales y revolucionarios, Editorial Crítica. Barcelona, 1979 (1a edició).

Jaria i Manzano, Jordi, "El dret, l'antropocè i la justicia", en Revista Catalana de Dret Ambiental, vol. VIII, núm. 2, 2016. 
Liu, Feng, Environmental Justice Análisis. Theories, methods and practice, Lewish Publishers. Londres, 2001 (1a edició).

López, Iván, "Justicia ambiental", en Eunomía. Revista en Cultura de la Legalidad, núm. 6, 2014.

Lucas, Robert Emerson, "On the mechanics of economic development", en Journal of Monetary Economics, núm. 22, 1988.

Margalef Llebaria, Joaquim i Tasias Valls, Joan, El Priorat, anàlisi d'una crisi productiva, Caixa d'Estalvis de Catalunya. Barcelona, 1985 (1a edició).

Martínez Alier, Joan, El ecologismo de los pobres. Conflictos ambientales y lenguajes de valoración, Icaria Editorial. Barcelona:, 2004 (1a edició).

Martínez Gil, Francisco Javier, La nueva cultura del agua en España, Bakeaz. Bilbao, 1997 (1a edició).

Ministerio de Industria, turismo y comercio, Sexto Plan General de Residuos Radioactivos, Ministerio de Industria, turismo y comercio. Madrid, 2006 (1a edició).

Moncada, Jesús, Camí de Sirga, Edicions 62. Barcelona, 1988 (1a edició).

Nadal i Oller, Jordi, El fracaso de la revolución industrial en España (18141913), Editorial Crítica. Barcelona, 2009 (1a edició).

Nogué Font, Joan i Sala Martí, Pere (coords.), Catàleg de paisatge del Camp de Tarragona, Generalitat de Catalunya. Barcelona, 2012 (1a edició).

Perpiñà i Grau, Romà, La crisi del Priorat, Edicions del Centre de Lectura. Reus, 1932 (1a edició).

Prada, Raúl, Subversiones indígenas, Muela del Diablo Editores. La Paz, 2008 (1a edició).

Pujadas Garriga, Marta, La creació d'un passiu ambiental a Catalunya. Història de la planta química de Flix al riu Ebre (1897-2013), Universitat Autònoma de Barcelona, 2015.

Romer, Paul M., "The origins of endogenous growth", en Journal of economic perspectives, vol. 8, núm. 1, 1994.

Saladié Gil, Sergi, "Anàlisi del procés d'implantació de centrals eòliques a les comarques meridionals de Catalunya”, en Revista de geografia, núm. 5, 2008.

Conflicte entre el paisatge i l'energia eòlica. El cas de les comarques meridionals de Catalunya, Pagès Editors. Lleida, 2018 (1a edició). 
Salter, Malcolm S., Innovation corrupted: The origins and legacy of Enron's collapse, Harvard University Press. Cambridge, 2008 (1a edició).

Shucksmith, Mark, "Endogenous development, social capital and social inclusion: Perspectives from LEADER in the UK", en Sociologia Ruralis, núm. 40, 2002.

Soler, Eduardo i Cortina, Albert (dirs.), Carta del paisatge del Priorat, Consell Comarcal del Priorat. Falset, 2012 (1a edició).

Sorribes i Monserrat, Jesús i Grau i Foch, Josep-Joan, La Ribera d'Ebre. Transformacions sòcio-econòmiques $i$ perspectives de futur, Caixa de Catalunya. Barcelona, 1989 (1a edició).

Swartz, Mimi i Watkins, Sherron, Power failure: the inside story of the collapse of Enron, Broadway Business. Nova York, 2004 (1a edició).

Tapia, Luis, Pensando la democracia geopolíticamente, CLACSO i Muela del Diablo Editores. La Paz, 2009 (1a edició).

Tarroja, Àlex (dir.), Anuari Territorial de Catalunya 2004, Societat Catalana d'Ordenació del Territori. Barcelona, 2005 (1a edició).

Castañer, Margarida i Mercadé, Montserrat (dirs.), Anuari

Territorial de Catalunya 2006, Societat Catalana d'Ordenació del Territori. Barcelona, 2007 (1a edició).

Wallerstein, Immanuel, El moderno sistema mundial, Siglo XXI Editores. Madrid, 2010 (2a edició en 4 volums).

Wenz, PS., Environmental Justice, State University of New York Press. Albany, 1988 (1a edició).

\section{Textos legislatius $\mathrm{i}$ jurisprudència}

Ley $18 / 1981$, de 1 de julio, sobre actuaciones en materia de aguas en Tarragona, Boletín Oficial del Estado, núm. 165, d'11 de juliol de 1981.

Decret 174/2002, d'11 de juny, regulador de la implantació de l'energia eòlica a Catalunya. Diari Oficial de la Generalitat de Catalunya, núm. 3664, 26 de juny de 2002.

Llei $8 / 2005$, de 8 de juny, de protecció, gestió i ordenació del paisatge. Diari Oficial de la Generalitat de Catalunya, núm. 4.407, de 16 de juny de 2005. 
Decret 343/2006, de 190 de setembre, pel qual es desenvolupa la Llei 8/2005, de 8 de juny, de protecció, gestió i ordenació del paisatge, i es regulen els estudis i informes d'impacte i integració paisatgística. Diari Oficial de la Generalitat de Catalunya, núm. 4.723, de 21 de setembre de 2006.

Tribunal Supremo (Sala segunda de lo Penal), STS 1012/2007, de 4 de desembre de 2007.

Instrumento de ratificación del Convenio Europeo del Paisaje (número 176 del Consejo de Europa), hecho en Florencia el 20 de octubre de 2000. Boletín Oficial del Estado, núm. 31, de 5 de febrer de 2008.

Acord GOV/4/2010, de 12 de gener, pel qual s'aprova definitivament el Pla territorial parcial del Camp de Tarragona. Diari Oficial de la Generalitat de Catalunya, núm. 5.559, de 3 de febrer de 2010.

Directiva 2010/75/UE del Parlamento europeo y del Consejo, de 24 de noviembre de 2010, sobre las emisiones industriales (prevención y control integrados de la contaminación), Diario Oficial de la Unión Europea, núm. 334, de 17 de desembre de 2010.

Orden ITC/3372/2011, de 22 de septiembre, por la que se concede la renovación de la autorización de explotación de la central nuclear Ascó I, Boletín Oficial del Estado, núm. 296, de 9 de desembre de 2011

Orden ITC/3373/2011, de 22 de septiembre, por la que se concede la renovación de la autorización de explotación de la central nuclear Ascó II, Boletín Oficial del Estado, núm. 296, de 9 de desembre de 2011.

Acord GOV/120/2012, de 20 de novembre, pel qual s'aprova la determinació de les zones de desenvolupament prioritari (ZDP) de parcs eòlics, Diari Oficial de la Generalitat de Catalunya, núm. 6.263, de 28 de novembre de 2012.

Orden ETU/610/2017, de 21 de junio, por la que se modifica la Orden ITC/3372/2011, de 22 de septiembre por la que se concede la renovación de la autorización de explotación de la central nuclear Ascó I, Boletín Oficial del Estado, núm. 152, de 27 de juny de 2017.

Orden ETU/611/2017, de 21 de junio, por la que se modifica la Orden ITC/3373/2011, de 22 de septiembre por la que se concede la renovación de la autorización de explotación de la central nuclear Ascó II, Boletín Oficial del Estado, núm. 152, de 27 de juny de 2017. 